NBER WORKING PAPER SERIES

\title{
NEW EVIDENCE ON THE CAUSAL LINK BETWEEN THE QUANTITY AND QUALITY OF CHILDREN
}

\author{
Joshua D. Angrist \\ Victor Lavy \\ Analia Schlosser \\ Working Paper 11835 \\ http://www.nber.org/papers/w11835 \\ NATIONAL BUREAU OF ECONOMIC RESEARCH \\ 1050 Massachusetts Avenue \\ Cambridge, MA 02138 \\ December 2005
}

Special thanks go to the staff of the Central Bureau of Statistics in Jerusalem, without whose assistance this project would not have been possible. We also thank Oded Galor, Omer Moav, Shaul Lach, Yaacov Ritov, Yona Rubinstein, Avi Simchon, David Weil and seminar participants at the 2005 NBER Summer Institute, Brown, and SUNYAlbany for helpful discussions and comments. The results reported here are preliminary and part of an ongoing study. The views expressed herein are those of the author(s) and do not necessarily reflect the views of the National Bureau of Economic Research.

(C)2005 by Joshua D. Angrist, Victor Lavy, and Analia Schlosser. All rights reserved. Short sections of text, not to exceed two paragraphs, may be quoted without explicit permission provided that full credit, including (C) notice, is given to the source. 
New Evidence on the Causal Link Between the Quantity and Quality of Children Joshua D. Angrist, Victor Lavy, and Analia Schlosser

NBER Working Paper No. 11835

December 2005

JEL No. J13, I31

\begin{abstract}
$\underline{\text { ABSTRACT }}$
A longstanding question in the economics of the family is the relationship between sibship size and subsequent human capital formation and economic welfare. If there is a "quantity-quality trade-off," then policies that discourage large families should lead to increased human capital, higher earnings, and, at the macro level, promote economic development. Ordinary least squares regression estimates and a large theoretical literature suggest that this is indeed the case. This paper provides new evidence on the child-quantity/child-quality trade-off. Our empirical strategy exploits exogenous variation in family size due to twin births and preferences for a mixed sibling-sex composition, as well as ethnic differences in the effects of these variables, and preferences for boys in some ethnic groups. We use these sources of variation to look at the causal effect of family size on completed educational attainment, fertility, and earnings. For the purposes of this analysis, we constructed a unique matched data set linking Israeli Census data with information on the demographic structure of families drawn from a population registry. Our results show no evidence of a quantity-quality trade-off, though some estimates suggest that first-born girls from large families marry sooner.

Joshua D. Angrist

Department of Economics

MIT, E52-353

50 Memorial Drive

Cambridge, MA 02142-1347

and NBER

angrist@mit.edu

Victor Lavy

Department of Economics

Hebrew University

Jerusalem 91905

Israel

and NBER

msvictor@huji.ac.il

Analia Schlosser

Department of Economics

Hebrew University

Jerusalem 91905

Israel

ani@mscc.huji.ac.il
\end{abstract}


FAMILY PlANNING: THE WAY TO PROSPERITY.

(A SLOGAN FOUND ON THE BACK OF INDONESIA'S FIVE-RUPIAH COIN)

\section{Introduction}

The question of how family size affects economic circumstances is one of the most enduring in social science. The earliest theoretical discussion of the role of family size in the determination of living standards was probably by Malthus, who famously argued that family size responds to income shocks in a manner that keeps living standards at a constant subsistence level. Beginning with Becker and Lewis (1973) and Becker and Tomes (1976), economists have replaced the Malthusian model with a theoretical framework that sees both the number of children and parental investment per child as choice variables that respond to economic forces. Part of this agenda is an attempt to reconcile the apparent paradox of declining family size in the face of economic growth with the superficially plausible presumption that children are indeed a normal good. The notion of a quantity-quality trade-off appears to provide this reconciliation: as parents get richer they demand children of higher "quality," (i.e., children who are more productive), without necessarily demanding more of them. In fact, because increases in quality can be interpreted as making children more expensive, the quantity-quality trade-off explains why families might get smaller as parents get richer.

On the policy side, the notion that smaller families and slower population growth are essential for development motivates many governments and international agencies to promote, or even to require smaller families. ${ }^{1}$ While this policy position often seems to be based on naive empiricism, both the Malthusian and the Becker and Lewis (1973) models provide some theoretical support for the view that large families keep living standards low. A negative causal relation between child quantity and parental investment also comes out of a number of sophisticated theoretical recent analyses of the role of the demographic transition in economic development (e.g., Galor and Weil, 2000; Hazan and Berdugo, 2002, and Moav, 2005). On the

\footnotetext{
${ }^{1}$ In addition to China, examples of government-sponsored family planning efforts include a forced-sterilization program in India and the aggressive public promotion of family planning in Mexico and Indonesia. These episodes are recounted in Weil (2005; Chapter 4), which also mentions the antinatalist slogan on the Indonesian Rupiah. Bongaarts (1994) notes that by 1990, 85 percent of people in the developing world lived in countries where the government considered the rates of fertility too high.
} 
other hand, the newer theories focus primarily on the quantity and quality implications of human capital accumulation. In these models, the effects of population-control efforts and similar policy interventions are less clear cut, a point we return to after discussing the estimates.

Most of the scholarly evidence pointing to an empirical quantity-quality trade-off comes from the widely observed negative association between family size on one hand and schooling or achievement on the other. For example, Leibowitz (1974) and Hanushek (1992) find that children's educational attainment and achievement growth are negatively correlated with family size. Many other micro-econometric and demographic studies show similar relations. ${ }^{2}$ The principal problem with research of this type is that such associations are not necessarily indicative of a causal relation. The fact that people raised in large families end up with less schooling than those raised in smaller families need not be due to family size per se. Rather, this correlation may simply reflect differences in parental education, earnings potential, or other potentially unobserved factors that affect both fertility and the home environment. The likelihood of omitted variables bias in estimates of the effects of childbearing is highlighted by Angrist and Evans (1998), who used multiple births and preferences for a mixed sibling-sex composition to construct instrumental variables (IV) estimates of the effect of family size on mothers' labor supply. IV estimates using both twins and same-sex instruments, while still negative, are considerably smaller than the corresponding OLS estimates.

This paper provides new evidence on the quantity-quality trade-off using exogenous variation in family size. Our approach adapts and extends the Angrist-Evans (AE-98) IV strategy to the estimation of effects of family size on various measures of "quality" that might be affected by the home environment. In particular, we look at the effect of third and higher births on first- and second-born children's completed schooling, adult earnings, and on marital status and fertility. Two of the instruments used here, as in AE-98, are dummies for multiple births at second birth and a dummy for same-sex sibling pairs in families with two

\footnotetext{
${ }^{2}$ See, e.g., the recent review by Schultz (2005). Johnson (1999) notes that the relation between family size and economic well being or growth is less clear cut at the time series or cross-country level. In contrast with Hanushek (1992), Guo and Vanwey (1999) show that control for family effects eliminates the relation between sibship size and intellectual development.
} 
or more children.

We also extend the AE-98 identification strategy in a number of ways. First, in addition to looking at families with two or more children, we exploit multiple third births and the effects of sibling-sex composition in families with three or more children. We also introduce a new source of exogenous variation in family size based on sharp differences in the effects of multiple births and sex-composition across ethnic groups in the Israeli population. For example, multiple births have a much larger effect on Jews of European or North American origin than on Jews of Asian or North African origin, since the latter chose to have large families even in the absence of a multiple birth. On the other hand, an all-female sibling sex composition leads to sharp rise in the number of children born to the Asia-Africa group, with relatively little effect on the fertility of ethnic Europeans and Israeli natives. Finally, we exploit preferences for boys at higher order births in the Asia-Africa subsample. Thus, our sample and identification strategies allow us to juxtapose the results from a number of different groups, using fertility shocks of different sorts and sizes, and over differing ranges of variation. Remarkably, all of this evidence points in the same direction: an exogenous increase in family size at second and higher births appears to have little effect on first and second born children, with the possible exception of an increase in the likelihood that female children marry.

Our paper comes on the heels of a substantial and growing literature attempting to link multiple births with measures of child quality. Rosenzweig and Wolpin (1980) appear to have been the first to use multiple births to estimate a child-quantity/child-quality trade-off. More recent estimates using multiple births include Duflo (1998), who looks at effects on child mortality in Indonesia; Black, Devereux, and Salvanes (2004), who estimate effects on education in Norway; and Caceres (2004), who looks at effects on private school enrollment in US Census data. Caceres (2004) also estimates effects on dropout status, teen pregnancy, and parents' marital status.

An important difference between our study and these earlier papers is that we have a wider range of outcomes than has been previously available for a research design of this type. Our outcomes come from a unique data set we constructed for the purposes of this project linking the 1983 and 1995 Israeli Census micro 
samples, which provide information on education, work, earnings, marriage, and childbearing, with detailed sibling information from the population registry. A second key difference is that the ethnic diversity of the Israeli population allows us to compare effects across families of different sizes and from different cultural traditions. Of particular interest here are results for the Asia-Africa subsample, that is, Sephardic Jews of North African and Middle Eastern origin. Those in this group have demographic and social characteristics much closer to developing country populations than do native-born Israelis or Israelis of European and North American stock. Finally, ours appears to be the first study to use sibling-sex composition to estimate the quality-quantity trade-off for a wide range of outcomes, or with a strong and well-documented first-stage. ${ }^{3}$

The paper is organized as follows. The next section describes the census-registry link and the construction of our more-than-two (2+) and more-than-three (3+) analysis samples. Section III discusses first-stage estimates and Section IV presents the main OLS and 2SLS results. We discuss the relation between our findings and earlier work in Section $\mathrm{V}$, focusing on the question of whether the case for an empirical quantity-quality trade-off should be evaluated in terms of parental inputs or child outcomes. Finally, Section VI concludes and suggests directions for further work.

\section{Data and Samples}

The main sources of data used here are the $20 \%$ public-use micro-data samples from the 1995 and 1983 Israeli censuses, linked with information on parents from the population registry. The Israeli census micro files are 1-in-5 random samples that include information collected on a fairly detailed long-form questionnaire similar to the one used to create the PUMS files for US censuses. ${ }^{4}$ The set of Jewish long-form

\footnotetext{
${ }^{3}$ Black, Devereux, and Salvanes (2004) briefly mention a failed effort in this direction. Conley and Glauber (2004) report estimates using sex-composition IVs, looking at grade retention and private school attendance, though problems with their research design make their results hard to interpret. Lee (2004) uses preferences for male children to construct an instrument for family size in Korea, where preferences for boys (as opposed to a mixed sibling-sex composition) are strong.

${ }^{4}$ Documentation can be found at the Israel Social Sciences Data Center web site: http://isdc.huji.ac.il/mainpage e.html (data sets 115 [1995 demographic file] and 301 [1983 files]). The Census includes residents of dwellings inside the State of Israel and Jewish settlements in the occupied territories. This includes residents
} 
respondents aged 18-60 provides our initial study sample. In the discussion that follows, we refer to these individuals as "subjects," to distinguish them from their parents and siblings, for whom we also collected data. Information on parents and siblings was obtained from the Israeli population registry maintained by the ministry of the interior. Conditional on an ongoing confidentiality review, the registry is available for use on a per-project basis inside the Central Bureau of Statistics (CBS) in a restricted-access Research Data Center. The link from census to registry is necessary for our purposes because in a sample of adult respondents, most of who no longer live with their parents and siblings, the census provides no information about sibship size, multiple births, or sibling sex composition. ${ }^{5}$

The Israeli population registry, our source of information on families of origin, contains updated administrative records for Israeli citizens and residents, whether currently living or dead, including most Israelis who have moved abroad. This data base also includes the Israeli ID numbers held by citizens and temporary residents. ID numbers are issued at birth for the native-born and upon arrival for immigrants. In addition to basic demographic information on individuals (date of birth, sex, country of birth, year of immigration, marital status, religion and nationality), the registry records parents' names and registrants' parents' ID numbers.

The construction of our analysis file proceeded by first using our subject's ID numbers to link to nonpublic-use versions of census long-form files that include ID numbers with registry records for as many subjects as we could find. In a second step, we used the registry to find subjects' mothers. Finally, once mothers were linked to census respondents, we then located all the mothers' children in the registry, whether or not these children appear in the census. In this manner we were able to observe the sex and birth dates of most adult census respondents' siblings.

abroad for less than one year, new immigrants, and non-citizen tourists and temporary residents living at the indicated address for more than a year.

${ }^{5}$ About $80 \%$ of the Israeli population is Jewish. The study sample is limited to Jews because census-topopulation-registry match rates are considerably lower for other groups. 


\section{Match Rates and Sample Selection}

Although coverage rates are reasonably good, not all census respondents appear in the population registry. Moreover, among those who can be found, information may be missing for mothers, and among those with mothers in the registry, some or all siblings may be missing. The likelihood of successful matches at each stage of our linkage effort is determined primarily by the inherent coverage limitations of the registry. Israel's population registry was first developed in 1948, not long after the creation of the state of Israel. Census enumerators went from house to house, simultaneously collecting information for the first census and for the administrative system that became the registry. Later, the registry was updated using vital statistics data. Thus, in principle, the sample of respondents available for a census interview in 1983 and 1995 should appear in the registry, along with their mothers' ID numbers, if they were resident in Israel in 1948, born in Israel after 1948, or immigrated to Israel after 1948.

The vast majority of our subjects do indeed appear in the registry. This can be seen in Table 1, the first two rows of which report starting sample sizes and subject-to-registry match rates, grouped according to whether subjects' parents were Israeli born, birth cohort, and whether subjects were Israeli-born (there are two panels in the table, one for each census). Subject-to-registry match rates range from 95-97 percent regardless of cohort and nativity. The most relevant coverage shortfall from our point of view is the failure to obtain an administrative record for subjects' mothers. This failure arises for a number of reasons. First, subject's mothers may have been alive but not at home in 1948 when the registry was created, or the mother may have been deceased. Second, and more importantly for most of our subjects, children are linked to mothers at the time they are born. We are therefore most likely to locate all of a subject's siblings when the subject's mother gave birth to all of her children in Israel.

The second row of each panel in Table 1 describes the impact of these record-keeping constraints on our census-to-registry match rates. The mothers of subjects with Israeli-born fathers were found 90 percent of the time for cohorts born after 1955. On the other hand, for those born before 1955, only 17 percent of mothers were found. Likewise, for those with foreign-born fathers, there is a similar age gradient in mothers' 
match rates. Even in this group, however, 87 percent of mothers were found for younger Israeli-born subjects in the 1995 census. The 1955 birth cohort marks a natural division for our purposes because mothers of subjects born after 1954 gave birth to most of their children in post-1948 Israel (the mothers in this group were mostly born after 1930, and, assuming childbirth starts at 18, this dates their first births at 1948 or later).

Given the match rates in Table 1, our analysis sample is clearly weighted towards post-1955 cohorts (i.e., 40 or younger in 1995). This accounts for about two-thirds of the 1995 population aged 18-60. Among the children of immigrant fathers, we're also much more likely to find mothers of the Israeli-born. The coverage rates for post-1955 Israeli-born cohorts seem high enough that we are likely to have information on mothers for a representative sample of younger cohorts regardless of fathers' nativity. For the purposes of analysis, we also used information on mothers in the matched sample to discard any remaining mothers who were born before 1930 (as the match rates for this group appeared to be very low anyway). Subjects with mothers whose first birth was before age 15 or after age 45 were also dropped. These further restrictions eliminate almost all subjects born before 1955, primarily because most of those born earlier have mothers born before the 1930 maternal age cutoff. We also restricted the sample of subjects with foreign-born mothers to those whose mothers arrived 1948 or later and before the age of 45 (in this case so that an immigrant mother with children is likely to have come with all her children, who would then have been included in the registry, either in the first census, or at the time IDs were issued to the family).

The final sample restriction retains only first and second-born subjects since these are the people exposed to the natural experiments exploited by the twins and sex-composition research design. Note that the restriction to first and second born subjects naturally eliminates a higher percentage of younger rather than older cohorts. This restriction also has a bigger effect on the Israeli-born children of foreign-born fathers than on other nativity groups, probably because these children were disproportionately likely to have been born to immigrant fathers who arrived with a large wave of immigrants from Asia and Africa in the 1950s. Immigrants from this group typically formed large families after arrival and will therefore have contributed more higher-parity births to the sample. 


\section{Description of Analysis Samples}

We work with two analysis samples, both described in Table 2. The first sample consists of firstborn subjects in families with two or more births (the $2+$ sample, $\mathrm{N}=89,445$ ). The second sample consists of first- and second-born subjects in families with three or more births (the $3+$ sample, $\mathrm{N}=65,671$ first-born and 53,070 second-born). These samples are defined conditional on the number of births instead of the number of children so that multiple-birth families can be included in the analysis samples without affecting the sample selection criteria. Twin subjects were dropped from both samples, however. ${ }^{6}$

Roughly three-quarters of the observations in each sample were drawn from the 1995 Census. On average, subjects were born in the mid-sixties and their mothers were in their early twenties at first birth. because out-of-wedlock childbearing is rare in Israel, especially among the cohorts studied here, virtually all subjects in both samples were born to married mothers. Naturally, however, some marriages have since broken up and some wives have been widowed. This is reflected in the 2003 marital status variables available in the registry. ${ }^{7}$

The Jewish Israeli population is often grouped by ethnicity, with Jews of African and Asian origin (AA; e.g., Moroccans), distinguished from Jews of European and North American (EA) origin. The 2+ sample is about 40 percent AA (defined using father's place of birth), while the $3+$ sample is over half AA. A preference for larger families in the AA population is also reflected in the statistics on numbers of children. Average family size ranges from 3.6 in the $2+$ sample to 4.2 in the $3+$ sample ( 4.3 for second-borns). In the AA subsample, however, the corresponding family sizes are about 4.3 and 4.7.

Table 2 also reports statistics on the variables used to construct instrumental variables. The twin rate

${ }^{6}$ A $3+$ sample defined as including first-born children from families with three or more children instead of three or more births would include all families with multiple second births. Likewise, sibling-sex composition can be defined across births without the need to determine which, say, of two twins, constitutes the second child.

${ }^{7}$ The $2+$ sample naturally includes the $3+$ sample. In the $3+$ sample, about 10 percent of the first- and secondborns have the same mother (both must appear in the $20 \%$ census sample and be in the relevant age range). We therefore cluster analyses that pool parities by mothers' ID. 
was $9 / 10$ of one percent at second birth in the $2+$ sample and 1 percent at third birth in the $3+$ sample, with similar rates in the AA and full samples. ${ }^{8}$ As expected, about 51 percent of births are male, regardless of birth order. Consequently, about half of the $2+$ sample was born into a same-sex sibling pair and about onequarter of the $3+$ sample was part of a same-sex threesome.

The outcome variables described in Table 2 measure subjects' educational attainment, labor market status and earnings, marital status and fertility, and the characteristics of subjects' spouses. Most Israelis are high school graduates, while 20 percent are college graduates. In the AA subsample, however, proportion of college graduates is much lower. Most of our subjects were working at the time they were interviewed and earned about 3000 shekels (about 1000 dollars) per month on average (including zeros). About 40 percent of subjects were married, though marriage rates are higher in the AA subsample. Table 2 also reports select descriptive statistics on spouses' characteristics in the sample of married subjects.

\section{First-stage Estimates}

The twins and same-sex first stages are described below in turn. Because the sex-composition model is somewhat more complicated in the $3+$ sample, these estimates are discussed in a separate subsection.

\section{Twins First-Stages}

A multiple second birth increases the number of siblings in the $2+$ sample by about half a child, a statistic reported in column 1 of Table 3, which shows first-stage estimates for the twins experiment. In particular, column 1 reports estimates of the coefficient $\alpha$ in the equation

$$
c_{i}=X_{i}^{\prime} \beta+\alpha t_{2 i}+\eta_{i}
$$

where $c_{i}$ is subject i's sibship size (including the subject), $X_{i}$ is a vector of controls that includes a full set of

\footnotetext{
${ }^{8}$ Note that the second-birth twin rate in the $3+$ sample is not comparable to the second birth twin rate in the $2+$ sample or the third-birth twin rate in the $3+$ sample because the $3+$ sample consists of those who had three or more births. Families with a second-born twin need not have a third birth to have three or more children. Families with a second-born twin that have a third birth have at least four children, and hence are relatively rare in the $3+$ sample.
} 
dummies for subjects' and subject's mothers' ages, Mothers' age at first birth, mothers' age at immigration (where relevant), fathers' and mothers' place of birth, census year, and a dummy for missing month of birth. The variable $t_{2 \mathrm{i}}$ indicates multiple second births in the $2+$ sample.

The Israeli twins- 2 first stage is smaller than the twins- 2 first stage of about .6 in the AE-98 sample, reflecting the fact that Israelis typically have larger families than Americans. Multiple births result in a smaller increase in family size when families would have been large even in the absence of a multiple birth. Within Israel, however, there are marked differences in the twins first-stage by ethnicity. This can be seen in column 2 of Table 2, which reports the twins- 2 main effect and an interaction term between twins- 2 and a dummy for Asia-Africa ethnicity $\left(a_{i}\right)$ in the equation

$$
c_{i}=X_{i}^{\prime} \beta+\alpha_{0} t_{2 i}+\alpha_{1} a_{i} t_{2 i}+\eta_{i}
$$

The twins- 2 main effect, $\alpha_{0}$, captures the effect of a multiple birth in the non-AA population, while the interaction term, $\alpha_{1}$, measures the AA/non-AA difference. ${ }^{9}$ The estimates in column 2 show that non-AA family size goes up by about .63 in response to a multiple birth (similar to the AE-98 first stage), while AA family size increases by only $.63-.45=.18$. Both $\alpha_{0}$ and $\alpha_{1}$ are very precisely estimated.

The remaining columns of Table 3 report the first-stage effect of a multiple third birth in the 3+ sample. Twins- 3 effects were estimated in the $3+$ sample by replacing $t_{2 \mathrm{i}}$ with $\mathrm{t}_{3 \mathrm{i}}$, a dummy for multiple third births, in equations (1) and (2). These results are reported in columns 3-4 for first-borns and columns 5-6 for the pooled sample of first- and second-borns. The first stage effect of a multiple birth is bigger in the $3+$ sample than in the $2+$ sample because the desire to have additional children diminishes as family size increases. For the same reason, the effect of $t_{3 i}$ differs less by ethnicity in the $3+$ sample than in the $2+$ sample, though, as the estimates in column 6 show, there is still a significant difference by ethnicity when first and second born subjects are pooled.

\footnotetext{
${ }^{9}$ The $\mathrm{a}_{\mathrm{i}}$ main effect is included in the vector of covariates, $\mathrm{X}_{\mathrm{i}}$.
} 


\section{Sibling-Sex Composition First-stage in the 2+ Sample}

The sex-composition first stages in the $2+$ sample are based on the following two models:

$$
\begin{aligned}
& c_{i}=X_{i}^{\prime} \beta+\gamma_{1} b_{1 i}+\gamma_{2} b_{2 i}+\pi_{s} s_{12 i}+\eta_{i} \\
& c_{i}=X_{i}^{\prime} \beta+\gamma_{1} b_{1 i}+\pi_{b} b_{12 i}+\pi_{g} g_{12 i}+\eta_{i}
\end{aligned}
$$

where $b_{1 i}$ (boy-first) and $b_{2 i}$ (boy-second) are dummies for boys born at first and second birth, the variable

$$
\mathrm{s}_{12 \mathrm{i}}=\mathrm{b}_{1 \mathrm{i}} \mathrm{b}_{2 \mathrm{i}}+\left(1-\mathrm{b}_{1 \mathrm{i}}\right)\left(1-\mathrm{b}_{2 \mathrm{i}}\right)
$$

is a dummy for same-sex sibling pairs, and

$$
\mathrm{b}_{12 \mathrm{i}}=\mathrm{b}_{1 \mathrm{i}} \mathrm{b}_{2 \mathrm{i}} \text { and } \mathrm{g}_{12 \mathrm{i}}=\left(1-\mathrm{b}_{1 \mathrm{i}}\right)\left(1-\mathrm{b}_{2 \mathrm{i}}\right)
$$

indicate two boys and two girls. Note also that $\mathrm{b}_{1 \mathrm{i}}$ indicates the subject's sex in the $2+$ sample, and that $\mathrm{s}_{12 \mathrm{i}}=$ $\mathrm{b}_{12 \mathrm{i}}+\mathrm{g}_{12 \mathrm{i}}$. The first model controls for boy-first and boy-second main effects, while the excluded instrument is a same-sex effect common to boy and girl pairs. The second model allows the effect of two boys and two girls to differ, though one of the boy main effects must be dropped since $\left\{b_{1 i}, b_{2 i}, b_{12 i}, g_{12 i}\right\}$ are linearly dependent. $^{10}$

The same-sex first-stage effects estimated using equation (3a) in the $2+$ sample, reported in column 1 of Table $4 \mathrm{a}$, are on the order of .08 children. This increase is due to an increase of a little over .03 in the likelihood of having more than two children, as well as smaller increases in the likelihood of having more than 3 and more than 4 children, as can be seen in columns 4,7 , and 8 , which report effects on dummies, $\mathrm{d}_{\mathrm{ki}}=1\left[\mathrm{c}_{\mathrm{i}}>\mathrm{k}\right]$, for $\mathrm{k}=2,3$, and 4. Same-sex sibship at first and second birth has an impact on the likelihood of having 4 or more children because, with probability one-half at each birth, families with a same-sex sibship outcome in earlier births find themselves with an all-boy or all-girl sibship at the next birth as well. Thus, $\mathrm{s}_{12 \mathrm{i}}=1$ shifts the distribution of fertility to the right in addition to increasing the likelihood that families have

\footnotetext{
${ }^{10}$ For example, $g_{12 \mathrm{i}}=1-\mathrm{b}_{1 \mathrm{i}}-\mathrm{b}_{2 \mathrm{i}}+\mathrm{b}_{12 \mathrm{i}}$. Control for boy-first and boy-second main effects is motivated by the fact that the same-sex interaction term is, in principle, correlated with the main effects (Angrist and Evans, 1998) when the probability of male birth exceeds .5. In practice, however, this matters little because both the correlation is small and because the main effects are small.
} 
more than two children. ${ }^{11}$

Sex-composition effects estimated using equation (3b), allowing for separate two-boys and two-girls coefficients, are reported in columns 2 and 3 of Table 4a. In addition to allowing different effects for boys and girls, the results reported in column 3 are from models that incorporate AA interaction terms, as with the twins estimates discussed above. The effect of two girls is .11 (s.e.=.015) while the effect of two boys is only $.039($ s.e. $=.015)$. The results allowing different effects by ethnicity generate an effect of two girls equal to .086 (s.e.=.017) in the non-AA population, with the AA effect of two girls is larger by .055 (s.e.=.032). In contrast, the two boys effect is only .056 (s.e.=.017) in the non-AA population, with the AA two-boys effect is smaller by .042 (s.e.=.031). As a result, the AA population appears to increase childbearing in response to the birth of two girls but not in response to the birth of two boys.

The remaining columns of Table $4 \mathrm{a}$ show the effect of sibling sex composition on the fertility distribution for fertility increments above two children. These results are summarized in Figure 1, which reports first-stage estimates of effects of $\mathrm{b}_{12 \mathrm{i}}$ and $\mathrm{g}_{12 \mathrm{i}}$ on $\mathrm{d}_{\mathrm{ki}}$ for $\mathrm{k}$ up to 9 , along with the associated confidence bands. In the AA population, $b_{12 \mathrm{i}}$ increases the likelihood that families have 3 or more children, with no significant effect at higher-order births. In contrast, the effect of two girls on $\mathrm{d}_{\mathrm{ki}}$ actually increases from $\mathrm{k}=2$ to $\mathrm{k}=3$, and then tails off gradually, with a marginally significant effect on the likelihood of having 7 or more children. ${ }^{12}$ Effects in the non-AA population drop off more sharply as the number of children increases, and

\footnotetext{
${ }^{11}$ The first-stage effect of an instrument on $c_{i}$ in the $2+$ sample can be shown to be the sum of the first stage effects on $\mathrm{d}_{\mathrm{ki}} ; \mathrm{k}=2, \ldots$ (Angrist and Imbens, 1995). In contrast with the results reported here, Angrist and Evans (1998) found similar same-sex effects on completed fertility and on the probability of having more than two children, i.e. on $\mathrm{d}_{2 \mathrm{i}}$, and therefore chose the latter as the endogenous variable of interest. This difference may be due to the fact that even in the face of a same-sex threesome, relatively few American couples are motivated to try again or because Angrist and Evans did not observe completed fertility. Because of the substantially larger first-stage for $c_{i}$ in the Israeli context, we use completed fertility as the endogenous variable.

${ }^{12}$ This increase, while counterintuitive at first blush, can be attributed to the fact that in the AA population that ends up with an all-girl triple, the likelihood of having more children is very large. Note that $P\left[c_{i}>k \mid c_{i} \geq k-1\right]=$ $\mathrm{P}\left[\mathrm{c}_{\mathrm{i}}>\mathrm{k} \mid \mathrm{c}_{\mathrm{i}} \geq \mathrm{k}\right] \mathrm{P}\left[\mathrm{c}_{\mathrm{i}} \geq \mathrm{k} \mid \mathrm{c}_{\mathrm{i}} \geq \mathrm{k}-1\right]$. The first stage effect can be written using the operator $\Delta_{\mathrm{s}}$, where this denotes the same-sex contrast in the relevant conditional probability of increasing fertility. We have $\Delta_{\mathrm{s}} \mathrm{P}\left[\mathrm{c}_{\mathrm{i}}>\mathrm{k} \mid \mathrm{c}_{\mathrm{i}} \geq \mathrm{k}-1\right]=\Delta_{\mathrm{s}}\left\{\mathrm{P}\left[\mathrm{c}_{\mathrm{i}}>\mathrm{k}\right.\right.$ $\left.\left.\mathrm{c}_{\mathrm{i}} \geq \mathrm{k}\right] \mathrm{P}\left[\mathrm{c}_{\mathrm{i}} \geq \mathrm{k} \mid \mathrm{c}_{\mathrm{i}} \geq \mathrm{k}-1\right]\right\}=\Delta_{\mathrm{s}} \mathrm{P}\left[\mathrm{c}_{\mathrm{i}}>\mathrm{k} \mid \mathrm{c}_{\mathrm{i}} \geq \mathrm{k}\right] \mathrm{P}\left[\mathrm{c}_{\mathrm{i}} \geq \mathrm{k} \mid \mathrm{c}_{\mathrm{i}} \geq \mathrm{k}-1, \mathrm{~s}_{\mathrm{i}}=1\right]+\Delta_{\mathrm{s}} \mathrm{P}\left[\mathrm{c}_{\mathrm{i}} \geq \mathrm{k} \mid \mathrm{c}_{\mathrm{i}} \geq \mathrm{k}-1\right] \mathrm{P}\left[\mathrm{c}_{\mathrm{i}}>\mathrm{k} \mid \mathrm{c}_{\mathrm{i}} \geq \mathrm{k}, \mathrm{s}_{\mathrm{i}}=0\right]$. For $\mathrm{AA}$, the incremental effects $\Delta_{\mathrm{S}} \mathrm{P}\left[\mathrm{c}_{\mathrm{i}}>\mathrm{k} \mid \mathrm{c}_{\mathrm{i}} \geq \mathrm{k}\right]$ and $\Delta_{\mathrm{s}} \mathrm{P}\left[\mathrm{c}_{\mathrm{i}} \geq \mathrm{k} \mid \mathrm{c}_{\mathrm{i}} \geq \mathrm{k}-1\right]$ are both substantial at $\mathrm{k}=3,4$.
} 
are similar for two boys and two girls. If anything, the non-AA population seems to increase childbearing more sharply in response to two boys than to two girls.

\section{Sibling-Sex Composition First Stages in the 3+ Sample}

The sex-composition first-stage in the $3+$ sample captures the effect of an all-boy or all-girl triple, controlling for the sex-composition of earlier births. Because a same-sex triple occurs only in families with same-sex pairs at first and second births, the model conditions on $b_{12 \mathrm{i}}$ and $\mathrm{g}_{12 \mathrm{i}}$, as well as a subject-sex main effect. An additional variable included in these models is a dummy for the sex of the third child, an effect which is defined conditional on a mixed-sex sibling pair at first and second birth (because for families with $\mathrm{b}_{12 \mathrm{i}}=1$, the boy-third effect is the same as having an all-male triple, while for families with $\mathrm{g}_{12 \mathrm{i}}=1$, the boythird effect is the same as having an all-female triple). The resulting model can be written as follows (we spell out only the model that allows for separate all-male and all-female effects):

$$
c_{i}=X_{i}^{\prime} \beta+\gamma_{1} b_{i}+\delta_{b} b_{12 i}+\delta_{g} g_{12 i}+\gamma_{3}\left(1-s_{12 i}\right) b_{3 i}+\lambda_{b} b_{123 i}+\lambda_{g} g_{123 i}+\eta_{i}
$$

where $b_{123 i}$ and $g_{123 i}$ are indicators for all-male and all-female triples and $b_{i}$ is subject sex (i.e., $b_{1 i}$ for firstborns and $\mathrm{b}_{2 \mathrm{i}}$ for second-borns). ${ }^{13}$

The first-stage effects using equation (4) in the $3+$ sample and the corresponding effects after incorporating the AA interactions are reported in Table 4b. Estimates for the first-borns sample are reported in columns 1-6. The overall effect of three girls is 0.181 (s.e.=.025), double the effect of three boys, 0.092 (s.e.=.023). As in the $2+$ sample, the effect of three girls is bigger in the AA population. The estimate for non-AA is .097 (s.e.=.032) and the increment for AA is .167 (s.e.=.051). In contrast, the effect of three boys is similar in the AA and non-AA population. Columns 7-8 in Table $4 \mathrm{~b}$ report estimates of equation (4) for total fertility in the pooled sample of first- and second-borns. The estimates are similar to those obtained in

\footnotetext{
${ }^{13}$ This model is almost saturated in the sense that it controls for all lower-order interaction terms in the estimation of the effects of the two samesex triples except for one: in the $\left(1-s_{12 i}\right) b_{3 i}$ term, we don't distinguish mixed sibling pairs according to whether a boy or girl was born first. There are at most 7 linearly independent terms in any saturated model that conditions on the sex-composition of the first three children, but we have 6 . A saturated model is
} 
the sample of first-borns only, though they are more precise due to the increased sample size.

Other columns in the table show the effect of sibling sex composition on the probability of having more than 3 and more than 4 children in the sample of first-borns and in the pooled sample of first- and second-borns. Since results in both samples are similar, we discuss effects on fertility increments for firstborns only. These results are summarized in Figure 2, which reports first-stage estimates of the effects of three-boys/girls $\left(\mathrm{b}_{123 \mathrm{i}} / \mathrm{g}_{123 \mathrm{i}}\right)$ on $\mathrm{d}_{\mathrm{ki}}$ for $\mathrm{k}=3$ to 10 , along with the associated confidence bands. The estimates are from a model that conditions on $b_{12 i}, g_{12 i}$ and $b_{i}$, and are estimated separately for the AA and non-AA population. In the AA population, $\mathrm{b}_{123 \mathrm{i}}$ increases the likelihood of having 4 or more children, with a small and marginally significant effect on the likelihood of having 5 or more children. The effect of three boys is similar in the AA and non-AA population. In contrast, the effect of three girls differs considerably by ethnicity. In the AA population, the effect of $\mathrm{g}_{123 \mathrm{i}}$ increases from $\mathrm{k}=3$ to $\mathrm{k}=4$ and then diminishes gradually for higher values of $\mathrm{k}$, remaining marginally significant even at $\mathrm{k}=10$. In the non-AA population, in contrast, the effect of $g_{123 i}$ is considerably smaller and differs little from the effect of $b_{123 i}$.

The Boy-3 ${ }^{\text {rd }}$ Instrument

The fourth and fifth rows of Table $4 \mathrm{~b}$ show the effect of having a boy at third birth $\left(b_{3 i}\right)$ in families with a mixed-sex sibship at first and second birth. A boy at third birth reduces childbearing in families that already have one boy by .080 (s.e.=.018). Results allowing different coefficients by ethnicity generate an effect of -.053 (s.e.=.023) in the non-AA population, while the AA interaction term adds a further .054 (s.e.=.035) to this reduction, though the difference between AA and non-AA is not significant. The Boy- $3^{\text {rd }}$ effect potentially provides an additional source of exogenous variation in fertility, beyond pure sexcomposition effects. We therefore add this to the instrument list for some of the 2SLS specifications discussed below. Figure 3 summarizes the effects of $b_{3 i}$ on fertility increments for families with a mixed-sex

obtained by replacing the single term $\left(1-\mathrm{s}_{12 \mathrm{i}}\right) \mathrm{b}_{3 \mathrm{i}}$ with two terms, with $\mathrm{b}_{1 \mathrm{i}}\left(1-\mathrm{b}_{2 \mathrm{i}}\right) \mathrm{b}_{3 \mathrm{i}}$ and $\mathrm{b}_{2 \mathrm{i}}\left(1-\mathrm{b}_{1 \mathrm{i}}\right) \mathrm{b}_{3 \mathrm{i}}$. In practice, this matters little. 
sibship at first and second birth, separately by ethnicity. In the AA population, $b_{3 \mathrm{i}}$ reduces the likelihood of having more than 4 children as well as the likelihood of higher order births, up to $k=7$, beyond which the effect is no longer significant. In the non-AA population, $b_{3 \mathrm{i}}$ reduces the likelihood of having 4 or more children, with no significant effect at higher order births.

\section{Pooled First-Stages Using the Full Set of Instruments}

In an attempt to increase precision, we also estimated specifications that combine twins and sexcomposition instruments. In particular, for the $2+$ sample, we combined the $t_{2 \mathrm{i}}, \mathrm{g}_{12 \mathrm{i}}$ and $\mathrm{b}_{12 \mathrm{i}}$. For the $3+$ sample, we combined the $t_{3 i}, g_{123 i}, b_{123 i}$ and $\left(1-s_{12 i}\right) b_{3 i}$ instruments, controlling for the characteristics of the first two births $\left(\mathrm{g}_{12 \mathrm{i}}, \mathrm{b}_{12 \mathrm{i}}, \mathrm{t}_{2 \mathrm{i}}\right.$ and $\left.\mathrm{b}_{\mathrm{i}}\right)$. These models also include AA interactions. Because the results are similar to those reported in Tables 3, 4a, and $4 \mathrm{~b}$, the pooled first stage is reported in the Appendix.

\section{OLS and 2SLS Estimates}

The causal effect of interest is the coefficient $\rho$ in the model

$$
\mathrm{y}_{\mathrm{i}}=\mathrm{W}_{\mathrm{i}}^{\prime} \mu+\rho \mathrm{c}_{\mathrm{i}}+\varepsilon_{\mathrm{i}}
$$

where $\mathrm{y}_{\mathrm{i}}$ is an outcome variable and $\mathrm{W}_{\mathrm{i}}$ includes the covariates $\mathrm{X}_{\mathrm{i}}$, as well as instrument-specific controls (e.g., $b_{i}$ ). In models without covariates, 2SLS estimates of this equation capture siblings' weighted average causal response (ACR) to the birth of an additional child - i.e., the effect of going from $c_{i}-1$ to $c_{i}$, averaged over $\mathrm{c}_{\mathrm{i}}$ - for those whose parents were induced to have an additional child by the instrument at hand. The ACR extends the local average treatment effect idea (LATE, Imbens and Angrist, 1994), a causal effect for those induced to increase childbearing by the instrument, to models with variable treatment intensity. The weighting function that lies behind the ACR is proportional to the CDF differences plotted in Figures 1-3 (Angrist and Imbens, 1995). With covariates, the interpretation of the ACR is slightly more elaborate, but the basic idea behind this interpretation is preserved. Of course, OLS estimates of equation (5) need not have a causal interpretation in models with or without controls. 
The outcome variables of interest capture the effects of family size on economic well-being and social status. In particular, we look at measures of subjects' educational attainment (highest grade completed, and indicators of high school completion, matriculation status, and college attendance), labor market status (indicators of work last year and last week, labor force participation, and hours worked last week) and earnings, marital status (indicators of being married at census day and married by age 21) and fertility (number of own children and indicators of having any or two or more children), and the characteristics of subjects' spouses (years of schooling, last week labor force participation and monthly earnings).

\section{The 2+ Sample}

As is typical for regressions of this sort, OLS estimates of the coefficient of family size in equation (5) imply adverse effects of increased family size on measures of human capital and economic circumstances. Larger families of origin are also associated with earlier marriage, increased fertility, and marriage to a less educated spouse. These results can be seen in column 2 of Table 5, which presents OLS estimates for firstborns in the $2+$ sample (column 1 reports the means). Not surprisingly, given the sample sizes, all the OLS estimates are very precise. Control for covariates reduces but does not eliminate this negative relationship, as can be seen in column 3 of the table.

In contrast with the adverse effects reflected in the OLS estimates of effects on schooling variables, 2SLS estimates show zero or even positive effects. These results appear in columns 4-8 of Table 5, which report 2SLS estimates for different sets of instruments. For example, the estimated effect on schooling using twins instruments with AA interaction terms, reported in column 4, is .101 (s.e.=.13). The corresponding estimates using sex-composition instruments with AA interaction terms, reported in column 7 is .222 (s.e.=.176). Combining both twins and sex-composition instruments generates an estimate of .15 (s.e. $=.104)$, reported in column 8 . Interestingly, the combination of instruments generates a substantial gain in precision relative to the use of each instrument set separately. So much so that the estimated schooling effect in the first row of column 8 is significantly different from the corresponding OLS estimate of -.145 reported in 
column 3. Likewise, the estimated effect on matriculation status, a key educational milestone in the Israeli milieu, is small, positive, and reasonably precise. ${ }^{14}$

This discussion highlights the fact that a key concern with the IV analysis is whether the estimates are precise enough to be informative. Of particular interest is the ability to distinguish IV estimates from the corresponding OLS benchmark. As it turns out, the estimates in column 8, constructed by pooling twins and sex-composition instruments with AA interaction terms, meet this standard of precision remarkably often. In particular, 12 of the 18 parameters presented in this column are estimated precisely enough that the associated $95 \%$ confidence interval exclude the corresponding OLS estimates reported in column 3 . Moreover, estimates of effects on the level and quality of schooling are very close to zero. The least precise estimates are those for the subject's own labor market outcomes and his or her spouse's outcomes. This echoes similar results reported by Black, Devereux, and Salvanes (2005), who also found insignificant but imprecise effects of family size on earnings.

A second set of noteworthy findings are those for marriage and fertility. The IV estimates of effects on marital status suggest that subjects from larger families are more likely to be married and got married sooner. Using both twins and sex-composition instruments, the estimated effects on marital status are significantly different from zero and substantially larger than the corresponding OLS estimates. On the other hand, the marriage effects generated by sex-composition instruments are much larger than the twins estimates, a point we return to below.

The marriage effects are paralleled by (and are perhaps the cause of) an increase in fertility: the combination-IV estimate of the effect on the probability of having any children is 0.078 , four times larger then the corresponding OLS estimate, 0.019. Estimates of effects on a dummy for having two or more children show a similar pattern. In addition to the likelihood that increased marriage rates increase fertility, these fertility effects may reflect an intergenerational causal link in preferences over family size, a possibility

\footnotetext{
${ }^{14}$ Angrist and Lavy (2004) report that even in a sample limited to those with exactly 12 years of schooling, matriculation certificate holders earn 13 percent more.
} 
suggested by Fernandez and Fogli (2005). Again, however, a cautionary note is that the fertility effects come from the sex-composition instruments and not twins. Also, since fertility estimates are based on fertility measures defined as of census day, i.e. 1983 or 1995, they could reflect an effect on earlier childbearing (possibly generated by earlier marriage) and not on completed fertility. Further record linkage should allow us to update subjects' fertility through 2004 and address this issue.

The last set of results in Table 5 is for spousal characteristics. Because the sample in this case is limited to married individuals, these results are potentially affected by selection bias. At the same time, while they should be interpreted with caution, the spousal results are of interest as an alternative measure of child quality, beyond human capital and labor market variables. One possible consequence of larger sibship sized is reduced parental investment in attributes that are rewarded in the marriage market. Consistent with this notion, and with the other OLS estimates in the table, the OLS estimates in the lower panel of Table 5 suggest that first-borns from larger families are married to spouses with fewer years of schooling, lower labor force participation and lower earnings. Again, however, the IV estimates in columns 4-8 show no significant effects, with signs that are more often positive than negative.

\section{The 3+ Sample}

Estimates in the $3+$ sample are broadly similar to those for the $2+$ sample, though there are some noteworthy differences. Results for first-borns in the $3+$ sample are reported in Table 6 a, which has a structure similar to Table 5. The OLS results in Tables 5 and 6 are virtually identical, though this is not surprising given the fact that the first-borns in the $3+$ sample are a sub-sample ( 73 percent) of the first-borns in the $2+$ sample. The 2 SLS estimates in the $3+$ sample exploit different sources of variation than in the $2+$ sample (twins at $3^{\text {rd }}$ birth instead of second; same-sex triples instead of pairs), so here we might expect some differences. The first key finding, however, is preserved: 2SLS estimates using both twins and sibling-sex composition generate no evidence of an effect on human capital or labor market variables.

Columns 2-6 in Table 6a parallel columns 4-8 in Table 5 in that these columns report results from the 
same sequence of instrument lists, with the modification that twins estimates now refer to the event of a multiple $3^{\text {rd }}$ birth and the sex-composition instruments are dummies for same-sex triples. An innovation in Table 6a, however, is the addition of column 7 reporting results combining all instruments (with AA interaction terms) and a dummy for boy- $3^{\text {rd }}$ (with an AA interaction term). This provides a modest further gain in precision.

Importantly, the marriage effects for first-borns in the $3+$ sample are smaller and less consistently significant than in the $2+$ sample. In particular, the twins instruments generate estimates that are now only marginally significantly different from zero for survey-date marital status, with no effect on early marriage. Likewise, the sex-composition instruments generally only marginally significant estimates on one marriage outcome, in this case, early marriage. This pattern of results therefore suggests there may be something special about sex-composition-induced increases in family size in the $2+$ sample. On the other hand, while the estimates in the $3+$ sample are no longer consistently significant, they still point in the direction of increased marriage.

A second difference between the results in Tables 5 and $6 \mathrm{a}$ is that some of the estimated effects on subjects' fertility in the $3+$ sample are negative and significant (e.g., -.125 with a standard error of .058 in column 7). This negative effect comes from a negative effect on the probability of having 3 or more children; effects on the probability of having any children or having more than two children are small and not significantly different from zero. Below we explore the marriage and fertility results further by looking at separate results for samples of men and women.

Because some concern has been raised about the existence of direct effects of the same-sex instrument on children's outcomes, thereby violating the exclusion restriction for this instrument, we also look at estimates omitting the same-sex instrument. These results, reported in column 8 , again provide no evidence of any adverse effects of family size. In general, same-sex instruments appear to generate smaller 2SLS estimates (i..e., closer to zero or less likely to be positive) than do twins instruments or the combination of twins with boy- $3^{\text {rd }}$. This contradicts Rosenzweig and Wolpin's (2000) conjecture regarding possible 
beneficial effects of having a sibling of the same sex.

Adding second-borns to the first-borns in the $3+$ sample roughly doubles the sample size. The OLS results are essentially unchanged by this addition, however, as can be seen in column 1 of Table $6 \mathrm{~b}$, which reports results using both first and second-borns. The IV estimates in Tables $6 \mathrm{a}$ and $6 \mathrm{~b}$ are also broadly similar. One important, though unsurprising, difference is that the estimates in Table $6 \mathrm{~b}$ are more precise. As a result, two thirds of the estimates in column 7 generate 95 percent confidence intervals that exclude the corresponding OLS estimates. A further change from Table 6a is that the total fertility estimate is smaller and no longer significantly different from zero. The marriage estimates using sex-composition instruments with AA interaction terms are now significant or close to it for both marital status outcomes (column 5). The combined-instruments estimate for early marriage is also significant (e.g., .035 with s.e. $=.017$ in column 7). On the other hand, the estimated effects on marital status in the pooled sample of first and second-borns are considerably smaller than the corresponding estimates in Table 5. On balance, therefore, the evidence for family-size effects on marital status come primarily from the $2+$ sample, though weaker positive effects appear in the $3+$ sample as well.

\section{Analyses by ethnicity and gender}

Large numbers of Sephardic Jews came to Israel from the Arab countries of Asia and North Africa in the 1950s. Initially, the Total Fertility Rate (TFR) of the AA population in Israel was 5-6, similar to that in many developing countries, while the TFR for Israeli Jews of European origin was just above 3. By the late $1990 \mathrm{~s}$, however, the TFR of the non-religious AA population had fallen to 2.2, only slightly higher than that of other non-religious Jewish groups (Friedlander, 2002). The sharp decline in TFR among the AA population occurred without government encouragement, and in the face of pronatalist tax and housing policies (Okun, 1997). In addition to having higher fertility, at least until recently, the AA group is less educated and has lower earnings than other (Jewish) ethnic groups. For example, only 12 percent of AA Jews in our $2+$ sample are college graduates, while the overall college graduation rate in the $2+$ sample is 20 
percent.

Most relevant for our purposes are the marked differences in the first-stage effects of multiple births and sex composition by ethnicity. The AA group increases fertility relatively little as a consequence of a multiple birth, especially a multiple second birth, since with high probability AA mothers who experienced a multiple birth were going to have more children anyway. On the other hand, an all-female sibship leads to sharply increased birth rates in the AA sample, much more than for other groups. Given the marked differences in fertility rates, socioeconomic status, and first-stage effects by ethnicity, results for the non-AA and AA samples might be expected to be different. To explore this possibility, we estimated models using the full set of instruments (i.e., corresponding to the last column in table 5, and to column 7 in tables $6 \mathrm{a}$, and 6b) separately for the AA and non-AA groups. These results are reported in Table 7.

OLS estimates generally show larger adverse effects in the non-AA sample than in the AA sample. In contrast, however, the 2SLS estimates are broadly similar in that the estimates for both the AA and nonAA groups generate no evidence of an effect on human capital or labor market variables. In fact, estimates for some of the schooling and labor market outcomes in the non-AA group are positive and significant (matriculation certificate and labor supply measures). As before, there is evidence for an increase or acceleration in marriage rates in both groups, while the fertility results are more mixed. The negative fertility effect comes mainly from the non-AA group while the positive early marriage effects are much larger in the AA subsample. The lack of an adverse effect of family size on child quality in the AA sample is particularly noteworthy in view of the non-western characteristics of this population and the effort in many developing countries to promote smaller families.

Also of interest in this context are separate results for men and women, especially in view of the effects on marital status discussed above. As with the results by ethnicity, we estimated separate results by gender using the full set of instruments, including Boy $-3^{\text {rd }}$ in the $3+$ sample. These are reported in Table 8 . The OLS estimates are almost identical for men and women. Again, the 2SLS estimates by gender show no evidence of any adverse effect on schooling or labor market variables for either group. In this case, some of 
the estimates on schooling variables for men are positive and significant. An especially important result in this context is the finding that the increase in marriage rates is much more pronounced for women. Moreover, as in the earlier pooled analysis, the effects are much larger in the $2+$ than in the $3+$ sample; in the latter, the effect on early marriage is insignificant and the effect on survey-date marital status is only marginally significant.

A further analysis using the twins and sex-composition instruments separately (not reported in the tables) shows that the marriage effects for women come primarily from the sex-composition instruments. This suggests that the marriage results for women in the $2+$ sample may be anomalous. A likely explanation is the pressure having a second-born sister puts on the eldest to marry. This is consistent with traditional Jewish values and can be traced back to the Biblical story of Rachel and Leah. ${ }^{15}$ The fact that the early marriage effect is larger for the more traditional AA subpopulation is also consistent with this story. The Rachel-and-Leah effect implies a possible violation of the exclusion restriction - though in the $2+$ sample only. But these marital status effects may also be a result of crowding. Older daughters in Israel who would like to set up an independent household may be tempted to marry sooner when crowded by younger sisters.

\section{Comparison with Previous Findings and Theoretical Implications}

Rosenzweig and Wolpin (1980) used multiple births to study quantity-quality trade-offs in a small sample from India. Their estimates point to a negative effect of multiple births on education, but their sample consisted of children who may not have completed their schooling, and included children born after the occurrence of a multiple birth (a selected sample). A more recent study by Black, Devereux and Salvanes

\footnotetext{
${ }^{15}$ Leah was the firstborn daughter of Laban, who was Issac's brother-in-law; Rachel was the second-born, and more beautiful, in the biblical account. Jacob, son of Issac, wished to marry Rachel, but was tricked into marrying the first-born by Laban, who claimed that the eldest daughter must marry first but also ultimately allowed Jacob to marry Rachel as well -- after a $2^{\text {nd }}$ long apprenticeship. This story may explain why the marriage effects are larger in the $2+$ sample than in the $3+$ sample. In the $2+$ sample the marriage effects on girls come from a second-born girl who may be pushing first-born girls to marry sooner. In the $3+$ sample, the same-sex effects on girls are generated by the $3^{\text {rd }}$-born girl (since we control for the sex of the second child), who may generate smaller effects than those generated by the nextoldest sibling.
} 
(2005) uses a large sample of administrative records to look at the effects of multiple births on schooling and earnings. Controlling for birth order, the occurrence of a multiple birth has no effect on these outcomes. An interesting difference between their results and ours is that the Norwegian families they study are much smaller than the Israeli families in our sample.

Two other recent studies have used IV methods with US census data to look at the effects of sibship size on schooling and private school enrollment among youth still co-resident with parents. Using twins instruments, Caceres (2004) finds a negative effect of family size on private school enrollment in some specifications and samples (as well as effects on room-sharing and parental divorce) but no effect on measures of human capital such as schooling or dropout status. Conley and Glauber (2004) use sibling-sex composition instruments to estimate effects on grade-retention and private school enrollment. Their results point to negative effects, though their research design is problematic. ${ }^{16}$ Finally, Qian (2004) uses regional and time variation in China's one-child policy, as well as multiple births, to estimate the effects of family size on school enrollment in China. Perhaps surprisingly, her estimates suggest that relaxation of the one-child policy increased the enrollment rates of first-born children.

Consistent with this related work, and against a background of our own OLS estimates showing strong adverse effects, our IV strategies generate little evidence for a quantity-quality trade-off in the sense of a causal link between sibship size and outcome variables describing the human capital, earnings, or social status of first- and second-born children. This suggests the OLS effects reflect substantial omitted variables bias. ${ }^{17}$ Our results reinforce and broaden the earlier findings in this area by simultaneously drawing on a number of sources of variation and including evidence from various fertility increments and from different

${ }^{16}$ Conley and Glauber (2004) omit the first-stage estimates that lie behind their estimates. The private school estimates in their study are significant only for "later-borns" (i.e., later than $2^{\text {nd }}$ born), a potentially endogenous sample in the sex-composition research design. The effects they report on grade repetition are more precise, but to a surprising extent given the likely size of the fertility first-stage in the 1990 PUMS (presumably the same as reported in Angrist and Evans, 1998).

\footnotetext{
${ }^{17}$ Shavit and Pierce (1991) present a detailed descriptive analysis of the correlation between sibship size and education for Israeli ethnic groups.
} 
family types. On the other hand, we do find some evidence of a possible "crowding effect" in the form of accelerated marriage rates for girls from large families. The fact that the marriage effects are highly localized, however, suggests they may be due to the social pressure a younger sister exerts on the eldest to marry, especially in traditional Jewish households. It seems unlikely this channel would give rise to a spurious absence of quantity-quality effects.

\section{Explanations and Implications for QQ Theory}

The first question this set of findings raises is what might account for the absence of a causal link between sibship size and child welfare, at least as measured here. One possibility is that in the face of larger families, whether due to an exogenous surprise in the case of twins or in response to an exogenous shift in the preferences for more children due to sex composition, parents adjust on margins other than quality inputs. ${ }^{18}$ For example, parents may work longer hours or take fewer or less expensive vacations (i.e., consume less leisure). Parents may also substitute away from personal as opposed to family consumption (e.g., by drinking less alcohol). Evidence on this point is difficult to obtain since consumption data rarely come in samples large enough or with the kind of retrospective family information needed to replicate our natural-experiments research design. Weighing against the "less leisure, more work" theory, however, are the AE-98 results showing no effect of additional childbearing on husbands' labor supply and a sharp negative effect of childbearing on wives labor supply and earnings.

The AE-98 results for wives raise the possibility of an explanation linked to female labor supply. Clearly one effect of additional childbearing is to increase the likelihood of at-home child-care for older siblings (an effect also documented by Gelbach, 2002). It may be that home care is better, on average, than commercial or other out-of-home care, at least in the families affected by the fertility shocks studied here. On the other hand, the evidence on this point, mostly coming out of welfare reform efforts to increase

\footnotetext{
${ }^{18}$ Although Israel, like many countries, offers tax concessions to larger families in the form of child allowances, these payments were low during the period subjects in our analysis samples were born (Manski and Mayshar, 2002). 
employment rates for single mothers, has been mixed, showing both positive and negative effects (see, e.g., Cherlin, 2004). The picture here may become clearer as additional evidence accumulates. In this context, however, it should also be noted that results for women on public assistance need not apply to other groups.

A third sort of explanation for the absence of a causal link between sibship size and the outcomes studied here might be called "marginally ineffective or irrelevant inputs." Using research designs similar to ours, Caceres (2004) and Glauber and Conley (2005) both find some evidence for a decreased likelihood of private school enrollment. Caceres also finds that children in larger families are more likely to share a room. This can be seen as paralleling the results reported here suggesting that girls from larger families marry sooner, since the latter may reflect a desire to leave a relatively crowded household. The private school, marriage, and room-sharing effects reflect changes in parental inputs. In practice, these inputs may matter little for children's life chances. For example, parents may incorrectly believe that a private school education is better (perhaps due to a misleading peer correlation) and children almost certainly prefer more space to less. But in the long run, these factors may be more consumption than investment, contributing little to human capital and life chances. Given the findings for these few inputs and the absence of significant or credible effects on longer-term outcomes, the notion that parents adjust inputs with low investment value appears to get some support.

The lack of a causal effect of family size on human capital and earnings appears inconsistent with a quantity-quality tradeoff in child-rearing. It should be noted, however, that in the original Becker-Lewis (1973) analysis, the quantity-quality trade-off was motivated as an endogenous shift in response to rising incomes. Becker and Lewis essentially assume that the income elasticity with respect to child quality is greater than that for child quantity, so that increases in income cause parents to shift from quantity to quality. At the same time, it is straightforward to show that exogenous increases in family size in a Becker-Lewistype setup (due, say to a change in contraceptive costs; p. S283) should reduce child quality since an increase in quantity increase the shadow price of quality. Along these lines, Rosenzweig and Wolpin (1980) similarly interpret the event of a twin birth as capturing the effect of a change in the relative price of quantity (actually 
a subsidy to the cost of further childbearing; p. 234). They argue that this price change should reduce quality unless quantity and quality are strong complements in parental utility functions.

A more recent theoretical literature focuses on the interaction between technological change, human capital, and quantity-quality trade-offs. Here the theoretical case for a quantity-quality trade-off is less clearcut. In Galor and Weil (2000), for example, parents substitute towards quality when the returns to human capital rise. In this sort of model, the effect of exogenous increases in the number of children on quality depends on the form of the utility function and other structural details.

While more recent theoretical discussions are less clear-cut than the original Becker framework, the traditional view has nevertheless helped to provide an intellectual foundation for policies that attempt to reduce family size in LDCs. Our results clearly raise questions about the nature and extent of the causal link running from numbers of children to family living standards. Of course, results for Israel, a relatively developed society, need not apply in a developing country setting. At the same time, we estimated effects for a sub-population of Asian and North African origin that has many of the demographic and cultural characteristics of a developing country population. The results for the AA and non-AA populations are similar.

\section{Summary and Directions for Further Work}

We use a unique sample combining census and population registry data to study the causal link running from sibship size to human capital and economic and social status later in life. Our research design exploits variation in fertility due to multiple births and preferences for a mixed sibling-sex composition, along with ethnicity interactions and preferences for a male child at third birth. The evidence is remarkably consistent across research designs and samples: while all instruments exhibit a strong first-stage relation, and OLS estimates are strongly negative, IV estimation generates no evidence for negative consequences of increased sibship size on outcomes. On the other hand, some estimates suggest that girls from larger families marry sooner. 
The results reported here are consistent with the findings from a number of recent studies using data from America, Norway, and China to explore the same sort of questions. What might explain the failure of an empirical quantity-quality trade-off to appear? One possibility is that the cost of children is borne by reducing parental consumption while holding quality constant. Another is that mothers' withdrawal from the labor force in response to childbirth is ultimately a net plus for older siblings. Finally, parents may reduce expenditure on inputs of low value to children, at least in our sample. In future work, we plan to investigate these possibilities with the aid of information from other samples and for additional outcome variables. On the data collection side, we hope to be able to use a number of strategies to improve match rates between the census and population registries and within families. 


\section{REFERENCES}

Angrist, J. and W. Evans, "Children and Their Parents' Labor Supply: Evidence from Exogenous Variation in Family Size," The American Economic Review 88(3), 1998, pp. 450-477.

Angrist, J. and G. Imbens, "Average Causal Response with Variable Treatment Intensity," Journal of the American Statistical Association, 90 (430), 1995, 431-442.

Angrist, J. and V. Lavy, "The Effect of High Stakes High School Achievement Awards: Evidence from a Group Rmndomized Trial,” mimeo, September 2004.

Becker, G. and H. G. Lewis, "On the Interaction between the Quantity and Quality of Children," Journal of Political Economy 81(2) part 2, 1973, pp. S279-S288.

Becker, G. and N. Tomes, "Child Endowments and the Quantity and Quality of Children," Journal of Political Economy 84(4) part 2, 1976, pp. S143-S162.

Behrman, J., R. Pollak and P. Taubman, "Family Resources, Family Size, and Access to Financing for College Education," Journal of Political Economy 97(2), 1989, pp. 398-419.

Black, S., P. J. Devereux and K. G. Salvanes, "The More the Merrier? The Effect of Family Composition on Children's Education," Quarterly Journal of Economics, 120(2), 2005, pp.669-700.

Bongaarts, J., "Population Policy Options in the Developing World," Science 263 (February), 1994, 771-776.

Caceres, J., "Impact of Family Size On Investment in Child Quality: Multiple Births as Natural Experiment," mimeo, Department of Economics, University of Maryland, 2004.

Cherlin, Andrew, "The Consequences of Welfare reform for Child Well-Being: What Have We Learned So Far and What are the Policy Implications," Paper presented at the American Sociological Association meetings, August, 2004.

Conley, D. and R. Glauber, "Parental Educational Investment and Children's Academic Risk: Estimates of the Impact of Sibship Size and Birth Order from Exogenous Variation in Fertility," National Bureau of Economic Research, Working paper 11302, 2005.

Conley, D. and R. Glauber, "Sibling Similarity and Difference in Socioeconomic Status: Life Course and Family Resource Effects," National Bureau of Economic Research, Working paper 11320, 2005.

Duflo, E., "Evaluating the Effect of Birth-Spacing on Child Mortality," mimeo, Department of Economics, Massachusetts Institute of Technology, 1998.

Fernandez, R. and A. Fogli, "Culture: An Empirical Investigation of Beliefs, Work, and Fertility," NBER Working Paper 11268, April 2005.

Friedlander, D., "Fertility in Israel: Is the transition to replacement level in sight?" Paper presented at the Expert Group Meeting of the UN Population Division on 'Completing the Fertility Transition', 2002.

Galor, O. and D. Weil, "Population, Technology, and Growth: From Malthusian Stagnation to the Demographic Transition and beyond," The American Economic Review 90(4), 2000, pp. 806-828.

Gelbach, J., "Public Schooling for Young Children and Maternal Labor Supply," American Economic Review 92(1), 2002, 307-322.

Guo, Guang and Leah K. Vanwey, "Sibship Size and Intellectual Development: Is the Relationship causal?," American Sociological Review 64(2), 1999, 169-187.

Hanushek, E., "The Trade-off between Child Quantity and Quality," Journal of Political Economy 100(1), 1992, pp. 84-117.

Hazan, M. and B. Berdugo, "Child Labor, Fertility and Economic Growth," The Economic Journal, 112 (October), 2002, pp. 810-828.

Imbens, G.W. and J. Angrist, "Identification and Estimation of Local Average Treatment Effects," Econometrica 62(2), 1994, 467-75.

Johnson, D. G., "Population and Economic Development," China Economic Review 10, 1999, pp. 1-16.

Lach, S., Y. Ritov and A. Simchon, "Mortality Across Generations: What is the Relationship?," mimeo, Hebrew University Department of Economics, April 2005. 
Lee, J., "Sibling Size and Investment in Children's Education: An Asian Instrument," IZA, Discussion Paper 1323, 2004.

Malthus, T., "An Essay on the Principle of Population,” London, Printed for J. Johnson, In St. Paul's Church-Yard, 1798.

Manski, C. and Y. Mayshar, "Private and Social Incentives for Fertility: Israeli Puzzles," National Bureau of Economic Research, Working paper 8984, 2002.

Moav, O., "Cheap Children and the Persistence of Poverty," The Economic Journal, 115 (January), 2005, pp. 88-110.

Okun, B. S., "Innovation and Adaptation in Fertility Transition: Jewish Immigrants to Israel from Muslim North Africa and the Middle East," Population Studies, 51, 1997, pp. 317-335.

Qian, N., "Quantity-Quality and the One Child Policy: The Positive Effect of Family Size on School Enrollment in China," Thesis chapter, Department of Economics, Massachusetts Institute of Technology, 2004.

Rosenzweig, M. and K. Wolpin, "Testing the Quantity-Quality Fertility Model: The Use of Twins as a Natural Experiment," Econometrica, 48(1), 1980, pp. 227-240.

Rosenzweig, M. and K. Wolpin, "Natural 'Natural Experiments' in Economics", Journal of Economic Literature, 38(4), 2000, pp. 827-74.

Schultz, T. P., "Effects of Fertility Decline on Family Well-Being: Evaluation of Population Programs," Draft for MacArthur Foundation Consultation meeting, Philadelphia, PA, 2005.

Shavit, Y. and J.L. Pierce, "Sibship Size and Educational Attainment in Nuclear and Extended Families: Arabs and Jews in Israel," American Sociological Review 56, 1991, 321-330.

Weil, David, Economic Growth, Boston: Addison-Wesley, 2005. 
Table 1: Match Rates and Sample Selection

\begin{tabular}{|c|c|c|c|c|c|c|c|c|c|c|c|c|}
\hline & \multicolumn{4}{|c|}{ Israeli-born Father } & \multicolumn{8}{|c|}{ Foreign-born Father } \\
\hline & \multirow{2}{*}{\multicolumn{2}{|c|}{$\begin{array}{c}\text { Subject } \\
\text { born }<1955 \\
(1)\end{array}$}} & \multirow{2}{*}{\multicolumn{2}{|c|}{$\begin{array}{c}\text { Subject } \\
\text { born } \geq 1955 \\
(2)\end{array}$}} & \multicolumn{4}{|c|}{ Foreign-born subejct } & \multicolumn{4}{|c|}{ Israeli-born Subject } \\
\hline & & & & & \multicolumn{2}{|c|}{$\begin{array}{c}\text { Subject } \\
\text { born<1955 } \\
(3) \\
\end{array}$} & \multicolumn{2}{|c|}{$\begin{array}{c}\text { Subject } \\
\text { born } \geq 1955 \\
(4)\end{array}$} & \multicolumn{2}{|c|}{$\begin{array}{c}\text { Subject } \\
\text { born<1955 } \\
(5)\end{array}$} & \multicolumn{2}{|c|}{$\begin{array}{c}\text { Subject } \\
\text { born } \geq 1955 \\
(6)\end{array}$} \\
\hline & \multicolumn{12}{|c|}{ A. 1995 census } \\
\hline All subjects & \multicolumn{2}{|c|}{9,453} & \multicolumn{2}{|c|}{56,534} & \multicolumn{2}{|c|}{118,633} & \multicolumn{2}{|c|}{72,340} & \multicolumn{2}{|c|}{58,767} & \multicolumn{2}{|c|}{161,331} \\
\hline Matched to registry $(\mathrm{N}, \%)$ & 9,057 & $95.8 \%$ & 54,073 & $95.6 \%$ & 115,123 & $97.0 \%$ & 68,788 & $95.0 \%$ & 57,098 & $97.2 \%$ & 156,096 & $96.8 \%$ \\
\hline Matched mother + siblings $(\mathrm{N}, \%)$ & 1,573 & $16.6 \%$ & 50,597 & $89.5 \%$ & 7,600 & $6.4 \%$ & 32,472 & $44.9 \%$ & 11,351 & $19.3 \%$ & 139,783 & $86.6 \%$ \\
\hline \multicolumn{13}{|l|}{ Selected sample } \\
\hline $\begin{array}{l}\text { Mothers born } \geq 1930 \text { whose age at } 1^{\text {st }} \text { birth } \varepsilon[15,45] \\
\text { of which: Israeli born mothers or immigrants who arrived }\end{array}$ & \multicolumn{2}{|l|}{494} & \multicolumn{2}{|l|}{48,683} & \multicolumn{2}{|l|}{1,166} & \multicolumn{2}{|l|}{26,217} & \multicolumn{2}{|l|}{2,556} & \multicolumn{2}{|l|}{119,928} \\
\hline $\begin{array}{l}\text { of which: first and second borns of families with } 2 \text { or more } \\
\text { births }\end{array}$ & \multicolumn{2}{|l|}{349} & \multicolumn{2}{|l|}{34,778} & \multicolumn{2}{|l|}{1,008} & 15,443 & & 1,937 & & 67,952 & \\
\hline Estimated fertility coverage: $86 \%$ & & & & & & & & & & & & \\
\hline & & & & & & B. 198 & census & & & & & \\
\hline All subjects & 11,0 & 049 & 12, & 665 & 160,4 & & 25, & 025 & 66,7 & 761 & 70,6 & \\
\hline Matched to registry $(\mathrm{N}, \%)$ & 9,704 & $87.8 \%$ & 10,867 & $85.8 \%$ & 140,932 & $87.8 \%$ & 20,691 & $82.7 \%$ & 60,105 & $90.0 \%$ & 62,141 & $87.9 \%$ \\
\hline Matched mother + siblings $(\mathrm{N}, \%)$ & 1,289 & $11.7 \%$ & 9,258 & $73.1 \%$ & 7,380 & $4.6 \%$ & 14,557 & $58.2 \%$ & 10,767 & $16.1 \%$ & 50,785 & $71.9 \%$ \\
\hline Selected sample & & & & & & & & & & & & \\
\hline $\begin{array}{l}\text { Mothers born } \geq 1930 \text { whose age at } 1^{\text {st }} \text { birth } \varepsilon[15,45] \\
\text { of which: Israeli born mothers or immigrants who arrived }\end{array}$ & 421 & & 7,854 & & 1,065 & & 9,197 & & 2,438 & & 34,560 & \\
\hline $\begin{array}{l}\text { since } 1948 \text { and before the age of } 45 \\
\text { of which: First and second borns of families with } 2 \text { or more }\end{array}$ & 318 & & 6,952 & & 1,045 & & 8,913 & & 2,138 & & 32,368 & \\
\hline births & 276 & & 5,834 & & 906 & & 5,889 & & 1,869 & & 21,744 & \\
\hline Estimated fertility coverage: $79 \%$ & & & & & & & & & & & & \\
\hline
\end{tabular}

Notes: The table reports sample sizes and match rates at each step of the link from census data to the population registry. The target population for linkage consists of Jewish census respondents in 1995 and 1983 aged 18-60. The table also shows the impact of sample selection criteria on sample sizes 
Table 2: Analysis Samples

\begin{tabular}{|c|c|c|c|c|c|c|}
\hline & \multicolumn{3}{|c|}{ Full } & \multicolumn{3}{|c|}{ Asia-Africa } \\
\hline & \multirow{2}{*}{$\begin{array}{c}2+ \\
1^{\text {st }} \text { borns } \\
\text { (1) }\end{array}$} & \multicolumn{2}{|c|}{$3+$} & \multirow{2}{*}{$\frac{2+}{1^{\text {st }} \text { borns }}$} & \multicolumn{2}{|c|}{$3+$} \\
\hline & & $\begin{array}{l}1^{\text {st }} \text { borns } \\
\text { (2) }\end{array}$ & $\begin{array}{c}2^{\text {nd }} \text { borns } \\
\text { (3) }\end{array}$ & & $\begin{array}{l}1^{\text {st }} \text { borns } \\
(5)\end{array}$ & $\begin{array}{c}2^{\text {nd }} \text { borns } \\
(6)\end{array}$ \\
\hline 1995 Census & 0.758 & 0.753 & 0.775 & 0.706 & 0.705 & 0.732 \\
\hline Mother married or widowed in 2003 & 0.910 & 0.926 & 0.932 & 0.921 & 0.932 & 0.937 \\
\hline \multicolumn{7}{|l|}{ Endogenous variables } \\
\hline \# of children & 3.63 & 4.22 & 4.32 & 4.31 & 4.67 & 4.76 \\
\hline More than 2 kids & 0.739 & - & - & 0.867 & - & - \\
\hline More than 3 kids & 0.400 & 0.545 & 0.572 & 0.593 & 0.686 & 0.704 \\
\hline \multicolumn{7}{|l|}{ Family composition } \\
\hline Twins at second birth & 0.009 & 0.006 & - & 0.009 & 0.006 & - \\
\hline Twins at third birth & - & 0.010 & 0.010 & - & 0.009 & 0.009 \\
\hline Boy at first birth & 0.517 & 0.518 & 0.527 & 0.518 & 0.518 & 0.528 \\
\hline Boy at second birth & 0.513 & 0.514 & 0.507 & 0.514 & 0.513 & 0.504 \\
\hline Boy at third birth & - & 0.513 & 0.516 & - & 0.508 & 0.515 \\
\hline Girl12=1 & 0.233 & 0.239 & 0.237 & 0.232 & 0.236 & 0.234 \\
\hline Boy $12=1$ & 0.265 & 0.272 & 0.272 & 0.265 & 0.267 & 0.267 \\
\hline Girl123=1 & - & 0.115 & 0.114 & - & 0.117 & 0.113 \\
\hline Boy $123=1$ & - & 0.140 & 0.141 & - & 0.138 & 0.138 \\
\hline \multicolumn{7}{|l|}{ Control Variables } \\
\hline Age on census day & 26.2 & 26.4 & 25.5 & 27.4 & 27.5 & 26.4 \\
\hline Year of birth & 1966 & 1965 & 1967 & 1964 & 1964 & 1965 \\
\hline Mother's age on census day & 49.0 & 48.8 & 50.4 & 49.7 & 49.5 & 50.8 \\
\hline Mother's year of birth & 1943 & 1943 & 1942 & 1942 & 1942 & 1941 \\
\hline Mother's age at 1 st birth & 22.7 & 22.2 & 22.1 & 22.0 & 21.7 & 21.7 \\
\hline $\begin{array}{l}\text { Mother's age at immigration } \\
\text { (for non-israeli mothers) }\end{array}$ & 17.4 & 15.7 & 15.9 & 15.6 & 15.4 & 15.7 \\
\hline \multicolumn{7}{|l|}{ Mother's ethnicity } \\
\hline Israel & 0.344 & 0.354 & 0.315 & 0.167 & 0.161 & 0.138 \\
\hline Asia-Africa & 0.397 & 0.468 & 0.507 & 0.792 & 0.804 & 0.830 \\
\hline Former USSR & 0.115 & 0.068 & 0.064 & 0.011 & 0.009 & 0.007 \\
\hline Europe-America & 0.144 & 0.111 & 0.114 & 0.030 & 0.025 & 0.025 \\
\hline \multicolumn{7}{|l|}{ Father's ethnicity } \\
\hline Israel & 0.274 & 0.282 & 0.248 & - & - & - \\
\hline Asia-Africa & 0.426 & 0.500 & 0.535 & 1.00 & 1.00 & 1.00 \\
\hline Former USSR & 0.115 & 0.068 & 0.068 & - & - & - \\
\hline Europe-America & 0.186 & 0.149 & 0.148 & - & - & - \\
\hline
\end{tabular}


Table 2 (cont.)

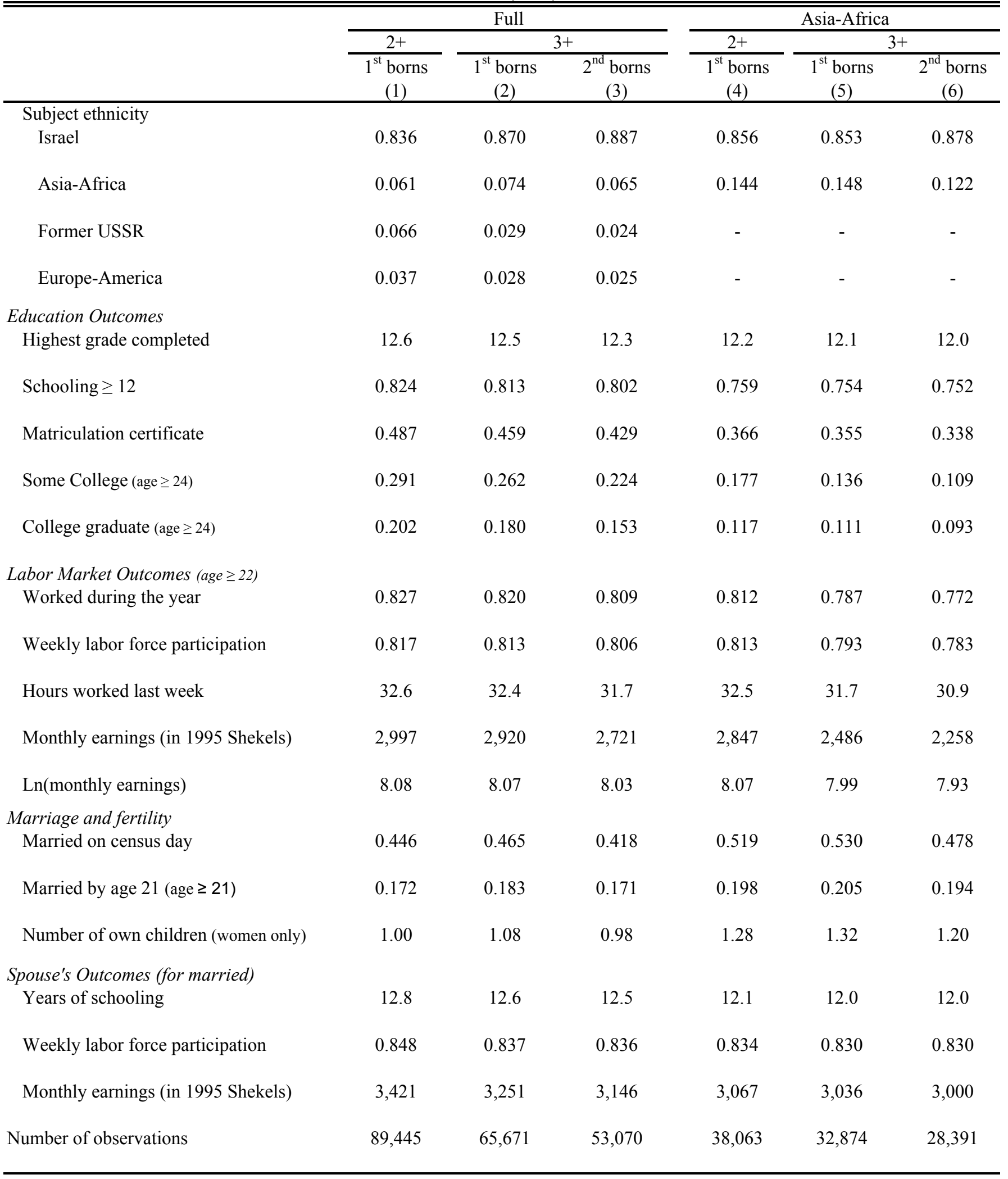

Notes: The table reports descriptive statistics for each of the 3 analysis samples used in the paper. The 2+ sample consists of first-born census subjects from families with two or more births including the subject. The $3+$ sample consists of first-born of first- and second-born census subjects from families with three or more births including the subject. The Asia-Africa subsample consists of census subjects whose fathers' ethnicity is identified as Asia-African in the census. 
Table 3: Twins First Stage

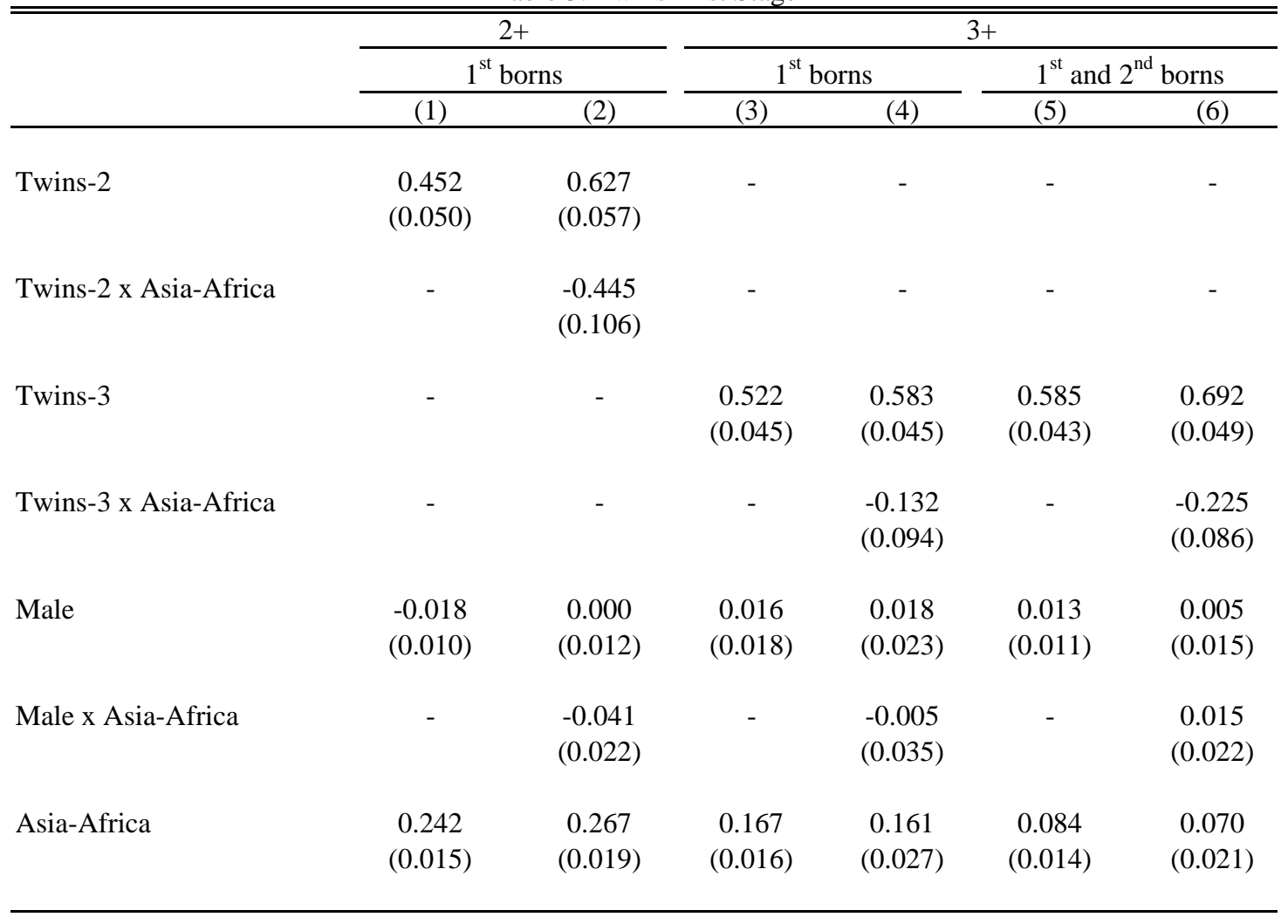

Notes: The table reports first-stage effects on number of children. The sample includes non-twins aged 18-60 in the 1983 and 1995 censuses as decribed in Table 1. In addition to the effects reported, the regressions include indicators for age, missing month of birth, mother's age, mother's age at first birth, mother's age at immigration (where relevant), father's and mother's place of birth, and census year. Regressions for columns 3-6 include also controls for girl12, boy12 and twins at second birth. Regressions for columns 5-6 include also indicators for second born and birth spacing between first and second birth. Robust standard errors are reported in parenthesis. Standard errors in columns 5-6 are clustered by mother's ID. 
Table 4a: Sex-Composition First Stage in 2+ Sample (First-borns)

\begin{tabular}{|c|c|c|c|c|c|c|c|c|c|c|c|c|}
\hline & \multicolumn{3}{|c|}{ \# of children } & \multicolumn{3}{|c|}{ More than 2} & \multicolumn{3}{|c|}{ More than 3} & \multicolumn{3}{|c|}{ More than 4} \\
\hline & $(1)$ & $(2)$ & (3) & $(4)$ & (5) & $(6)$ & $(7)$ & $(8)$ & (9) & (10) & $(11)$ & $(12)$ \\
\hline Samesex12 & $\begin{array}{c}0.074 \\
(0.010)\end{array}$ & - & - & $\begin{array}{c}0.030 \\
(0.003)\end{array}$ & - & - & $\begin{array}{c}0.022 \\
(0.003)\end{array}$ & - & - & $\begin{array}{c}0.010 \\
(0.002)\end{array}$ & - & - \\
\hline Girl12 & - & $\begin{array}{c}0.110 \\
(0.015)\end{array}$ & $\begin{array}{c}0.086 \\
(0.017)\end{array}$ & - & $\begin{array}{c}0.028 \\
(0.004)\end{array}$ & $\begin{array}{c}0.032 \\
(0.006)\end{array}$ & - & $\begin{array}{c}0.032 \\
(0.004)\end{array}$ & $\begin{array}{c}0.028 \\
(0.005)\end{array}$ & - & $\begin{array}{c}0.022 \\
(0.004)\end{array}$ & $\begin{array}{c}0.013 \\
(0.004)\end{array}$ \\
\hline Girl12 x Asia-Africa & - & - & $\begin{array}{c}0.055 \\
(0.032)\end{array}$ & - & - & $\begin{array}{l}-0.010 \\
(0.007)\end{array}$ & - & - & $\begin{array}{c}0.010 \\
(0.009)\end{array}$ & - & - & $\begin{array}{c}0.022 \\
(0.008)\end{array}$ \\
\hline Boy12 & - & $\begin{array}{c}0.039 \\
(0.015)\end{array}$ & $\begin{array}{c}0.056 \\
(0.017)\end{array}$ & - & $\begin{array}{c}0.032 \\
(0.004)\end{array}$ & $\begin{array}{c}0.046 \\
(0.005)\end{array}$ & - & $\begin{array}{c}0.012 \\
(0.004)\end{array}$ & $\begin{array}{c}0.018 \\
(0.005)\end{array}$ & - & $\begin{array}{c}-0.001 \\
(0.003)\end{array}$ & $\begin{array}{l}-0.002 \\
(0.004)\end{array}$ \\
\hline Boy12 x Asia-Africa & - & - & $\begin{array}{l}-0.042 \\
(0.031)\end{array}$ & - & - & $\begin{array}{c}-0.032 \\
(0.007)\end{array}$ & - & - & $\begin{array}{l}-0.013 \\
(0.008)\end{array}$ & - & - & $\begin{array}{c}0.002 \\
(0.007)\end{array}$ \\
\hline Boy1 & $\begin{array}{l}-0.020 \\
(0.010)\end{array}$ & $\begin{array}{c}0.015 \\
(0.015)\end{array}$ & $\begin{array}{c}0.012 \\
(0.017)\end{array}$ & $\begin{array}{c}0.003 \\
(0.003)\end{array}$ & $\begin{array}{c}0.001 \\
(0.004)\end{array}$ & $\begin{array}{c}0.000 \\
(0.006)\end{array}$ & $\begin{array}{l}-0.009 \\
(0.003)\end{array}$ & $\begin{array}{c}0.002 \\
(0.004)\end{array}$ & $\begin{array}{c}0.003 \\
(0.005)\end{array}$ & $\begin{array}{l}-0.008 \\
(0.002)\end{array}$ & $\begin{array}{c}0.003 \\
(0.003)\end{array}$ & $\begin{array}{c}0.004 \\
(0.004)\end{array}$ \\
\hline Boy1 x Asia-Africa & - & - & $\begin{array}{c}0.007 \\
(0.031)\end{array}$ & - & - & $\begin{array}{c}0.002 \\
(0.007)\end{array}$ & - & - & $\begin{array}{l}-0.002 \\
(0.008)\end{array}$ & - & - & $\begin{array}{l}-0.002 \\
(0.007)\end{array}$ \\
\hline Boy2 & $\begin{array}{l}-0.038 \\
(0.010)\end{array}$ & - & - & $\begin{array}{c}0.000 \\
(0.003)\end{array}$ & - & - & $\begin{array}{l}-0.011 \\
(0.003)\end{array}$ & - & - & $\begin{array}{c}-0.012 \\
(0.002)\end{array}$ & - & - \\
\hline Asia-Africa & $\begin{array}{c}0.242 \\
(0.015)\end{array}$ & $\begin{array}{c}0.242 \\
(0.015)\end{array}$ & $\begin{array}{c}0.236 \\
(0.024)\end{array}$ & $\begin{array}{c}0.043 \\
(0.004)\end{array}$ & $\begin{array}{c}0.043 \\
(0.004)\end{array}$ & $\begin{array}{c}0.053 \\
(0.006)\end{array}$ & $\begin{array}{c}0.098 \\
(0.005)\end{array}$ & $\begin{array}{c}0.098 \\
(0.005)\end{array}$ & $\begin{array}{c}0.100 \\
(0.007)\end{array}$ & $\begin{array}{c}0.065 \\
(0.004)\end{array}$ & $\begin{array}{c}0.065 \\
(0.004)\end{array}$ & $\begin{array}{c}0.061 \\
(0.006)\end{array}$ \\
\hline
\end{tabular}

Notes: The table reports first-stage effects on number of children and binary indicators for having more than 2, 3 and 4 kids. The sample includes first born non-twins from families with 2 or more births. Regression estimates are from models that include the control variables specified in Table 3. Regressions for columns 1,4,7 and 10 control also for boy at second birth. Robust standard errors are reported in parenthesis. 
Table 4b: Sex-Composition First Stage in 3+ Sample (First- and Second-borns)

\begin{tabular}{|c|c|c|c|c|c|c|c|c|c|c|c|c|}
\hline & \multicolumn{6}{|c|}{ First Borns } & \multicolumn{6}{|c|}{ First and Second Borns } \\
\hline & \multicolumn{2}{|c|}{ \# of children } & \multicolumn{2}{|c|}{ More than 3} & \multicolumn{2}{|c|}{ More than 4} & \multicolumn{2}{|c|}{ \# of children } & \multicolumn{2}{|c|}{ More than 3} & \multicolumn{2}{|c|}{ More than 4} \\
\hline & $(1)$ & $(2)$ & $(3)$ & $(4)$ & $(5)$ & $(6)$ & $(7)$ & $(8)$ & $(9)$ & $(10)$ & $(11)$ & $(12)$ \\
\hline Girl123 & $\begin{array}{c}0.181 \\
(0.025)\end{array}$ & $\begin{array}{c}0.097 \\
(0.032)\end{array}$ & $\begin{array}{c}0.050 \\
(0.007)\end{array}$ & $\begin{array}{c}0.044 \\
(0.011)\end{array}$ & $\begin{array}{c}0.051 \\
(0.007)\end{array}$ & $\begin{array}{c}0.032 \\
(0.008)\end{array}$ & $\begin{array}{c}0.185 \\
(0.022)\end{array}$ & $\begin{array}{c}0.075 \\
(0.027)\end{array}$ & $\begin{array}{c}0.050 \\
(0.006)\end{array}$ & $\begin{array}{c}0.043 \\
(0.009)\end{array}$ & $\begin{array}{c}0.055 \\
(0.006)\end{array}$ & $\begin{array}{c}0.028 \\
(0.007)\end{array}$ \\
\hline Girl123 x Asia-Africa & - & $\begin{array}{c}0.167 \\
(0.051)\end{array}$ & - & $\begin{array}{c}0.011 \\
(0.015)\end{array}$ & - & $\begin{array}{c}0.039 \\
(0.013)\end{array}$ & - & $\begin{array}{c}0.214 \\
(0.043)\end{array}$ & - & $\begin{array}{c}0.013 \\
(0.012)\end{array}$ & - & $\begin{array}{c}0.052 \\
(0.011)\end{array}$ \\
\hline Boy123 & $\begin{array}{c}0.092 \\
(0.023)\end{array}$ & $\begin{array}{c}0.095 \\
(0.029)\end{array}$ & $\begin{array}{c}0.052 \\
(0.007)\end{array}$ & $\begin{array}{c}0.067 \\
(0.010)\end{array}$ & $\begin{array}{c}0.023 \\
(0.006)\end{array}$ & $\begin{array}{c}0.023 \\
(0.007)\end{array}$ & $\begin{array}{c}0.063 \\
(0.021)\end{array}$ & $\begin{array}{c}0.068 \\
(0.025)\end{array}$ & $\begin{array}{c}0.054 \\
(0.006)\end{array}$ & $\begin{array}{c}0.067 \\
(0.009)\end{array}$ & $\begin{array}{c}0.020 \\
(0.005)\end{array}$ & $\begin{array}{c}0.020 \\
(0.006)\end{array}$ \\
\hline Boy123 x Asia-Africa & - & $\begin{array}{l}-0.007 \\
(0.047)\end{array}$ & - & $\begin{array}{c}-0.032 \\
(0.014)\end{array}$ & - & $\begin{array}{c}0.001 \\
(0.012)\end{array}$ & - & $\begin{array}{c}-0.008 \\
(0.041)\end{array}$ & - & $\begin{array}{l}-0.027 \\
(0.012)\end{array}$ & - & $\begin{array}{c}0.000 \\
(0.011)\end{array}$ \\
\hline Boy3 x (1-samesex12) & $\begin{array}{l}-0.080 \\
(0.018)\end{array}$ & $\begin{array}{l}-0.053 \\
(0.023)\end{array}$ & $\begin{array}{c}0.007 \\
(0.005)\end{array}$ & $\begin{array}{l}-0.027 \\
(0.008)\end{array}$ & $\begin{array}{l}-0.019 \\
(0.005)\end{array}$ & $\begin{array}{l}-0.009 \\
(0.006)\end{array}$ & $\begin{array}{l}-0.079 \\
(0.015)\end{array}$ & $\begin{array}{l}-0.047 \\
(0.019)\end{array}$ & $\begin{array}{l}-0.030 \\
(0.004)\end{array}$ & $\begin{array}{l}-0.023 \\
(0.007)\end{array}$ & $\begin{array}{l}-0.019 \\
(0.004)\end{array}$ & $\begin{array}{l}-0.007 \\
(0.005)\end{array}$ \\
\hline Boy3 x (1-samesex12) x Asia-Africa & - & $\begin{array}{l}-0.054 \\
(0.035)\end{array}$ & - & $\begin{array}{l}-0.010 \\
(0.010)\end{array}$ & - & $\begin{array}{l}-0.020 \\
(0.009)\end{array}$ & - & $\begin{array}{c}-0.061 \\
(0.030)\end{array}$ & - & $\begin{array}{l}-0.013 \\
(0.009)\end{array}$ & - & $\begin{array}{l}-0.023 \\
(0.008)\end{array}$ \\
\hline Subject $=$ boy & $\begin{array}{c}0.014 \\
(0.018)\end{array}$ & $\begin{array}{c}0.016 \\
(0.023)\end{array}$ & $\begin{array}{c}0.000 \\
(0.005)\end{array}$ & $\begin{array}{c}0.003 \\
(0.008)\end{array}$ & $\begin{array}{c}0.004 \\
(0.005)\end{array}$ & $\begin{array}{c}0.006 \\
(0.006)\end{array}$ & $\begin{array}{c}0.013 \\
(0.011)\end{array}$ & $\begin{array}{c}0.004 \\
(0.015)\end{array}$ & $\begin{array}{c}-0.002 \\
(0.003)\end{array}$ & $\begin{array}{l}-0.002 \\
(0.005)\end{array}$ & $\begin{array}{c}0.004 \\
(0.003)\end{array}$ & $\begin{array}{c}0.003 \\
(0.004)\end{array}$ \\
\hline$($ Subject $=$ boy $) \times$ Asia-Africa & - & $\begin{array}{l}-0.003 \\
(0.035)\end{array}$ & - & $\begin{array}{l}-0.005 \\
(0.010)\end{array}$ & - & $\begin{array}{l}-0.006 \\
(0.009)\end{array}$ & - & $\begin{array}{c}0.017 \\
(0.022)\end{array}$ & - & $\begin{array}{c}0.001 \\
(0.006)\end{array}$ & - & $\begin{array}{c}0.001 \\
(0.006)\end{array}$ \\
\hline Asia-Africa & $\begin{array}{c}0.164 \\
(0.016)\end{array}$ & $\begin{array}{c}0.182 \\
(0.032)\end{array}$ & $\begin{array}{c}0.086 \\
(0.006)\end{array}$ & $\begin{array}{c}0.095 \\
(0.010)\end{array}$ & $\begin{array}{c}0.062 \\
(0.005)\end{array}$ & $\begin{array}{c}0.070 \\
(0.009)\end{array}$ & $\begin{array}{c}0.083 \\
(0.014)\end{array}$ & $\begin{array}{c}0.096 \\
(0.026)\end{array}$ & $\begin{array}{c}0.064 \\
(0.005)\end{array}$ & $\begin{array}{c}0.072 \\
(0.008)\end{array}$ & $\begin{array}{c}0.045 \\
(0.004)\end{array}$ & $\begin{array}{c}0.052 \\
(0.007)\end{array}$ \\
\hline
\end{tabular}

Notes: The table reports first-stage effects on number of children and binary indicators for having more than 3 and 4 kids. The sample for columns 1-6 includes first born non-twins from families with 3 or more births. The sample for columns 7-12 includes first and second born non-twins from families with 3 or more births. Regression estimates are from models that include the control variables specified in table 3. Standard errors in columns 7-12 are clustered by mother's ID. 


\begin{tabular}{|c|c|c|c|c|c|c|c|c|}
\hline & \multirow[b]{2}{*}{$\begin{array}{l}\text { Means } \\
\text { (1) }\end{array}$} & \multicolumn{2}{|c|}{ OLS } & \multicolumn{5}{|c|}{ 2SLS -- Instrument list } \\
\hline Outcome & & $\begin{array}{c}\text { basic } \\
\text { covs. } \\
(2)\end{array}$ & $\begin{array}{l}\text { all } \\
\text { covs. } \\
(3)\end{array}$ & $\begin{array}{l}\text { twins } \\
\text { (4) }\end{array}$ & $\begin{array}{l}\text { twins, } \\
\text { twinsAA } \\
(5)\end{array}$ & $\begin{array}{c}\text { girl12, } \\
\text { boy12 } \\
(6)\end{array}$ & $\begin{array}{c}\text { girl12, } \\
\text { boyl2, } \\
\text { girl12AA, } \\
\text { boy12AA } \\
(7)\end{array}$ & $\begin{array}{l}\text { all } \\
(8)\end{array}$ \\
\hline \multicolumn{9}{|l|}{ Schooling } \\
\hline Highest grade completed & 12.6 & $\begin{array}{l}-0.252 \\
(0.005)\end{array}$ & $\begin{array}{l}-0.145 \\
(0.005)\end{array}$ & $\begin{array}{c}0.152 \\
(0.159)\end{array}$ & $\begin{array}{c}0.101 \\
(0.130)\end{array}$ & $\begin{array}{c}0.295 \\
(0.184)\end{array}$ & $\begin{array}{c}0.222 \\
(0.176)\end{array}$ & $\begin{array}{c}0.150 \\
(0.104)\end{array}$ \\
\hline Years of schooling $\geq 12$ & 0.824 & $\begin{array}{c}-0.037 \\
(0.001)\end{array}$ & $\begin{array}{l}-0.029 \\
(0.001)\end{array}$ & $\begin{array}{c}0.023 \\
(0.027)\end{array}$ & $\begin{array}{c}0.021 \\
(0.021)\end{array}$ & $\begin{array}{l}-0.009 \\
(0.028)\end{array}$ & $\begin{array}{l}-0.016 \\
(0.028)\end{array}$ & $\begin{array}{c}0.003 \\
(0.017)\end{array}$ \\
\hline Matriculation certificate & 0.487 & $\begin{array}{c}-0.054 \\
(0.001)\end{array}$ & $\begin{array}{l}-0.033 \\
(0.001)\end{array}$ & $\begin{array}{l}-0.009 \\
(0.036)\end{array}$ & $\begin{array}{l}-0.004 \\
(0.033)\end{array}$ & $\begin{array}{c}0.100 \\
(0.043)\end{array}$ & $\begin{array}{c}0.077 \\
(0.040)\end{array}$ & $\begin{array}{c}0.033 \\
(0.025)\end{array}$ \\
\hline Some College (age $\geq 24$ ) & 0.291 & $\begin{array}{c}-0.049 \\
(0.001)\end{array}$ & $\begin{array}{l}-0.023 \\
(0.001)\end{array}$ & $\begin{array}{c}0.012 \\
(0.048)\end{array}$ & $\begin{array}{c}0.023 \\
(0.045)\end{array}$ & $\begin{array}{c}0.089 \\
(0.048)\end{array}$ & $\begin{array}{c}0.089 \\
(0.046)\end{array}$ & $\begin{array}{c}0.054 \\
(0.031)\end{array}$ \\
\hline College graduate (age $\geq 24$ ) & 0.202 & $\begin{array}{l}-0.036 \\
(0.001)\end{array}$ & $\begin{array}{l}-0.015 \\
(0.001)\end{array}$ & $\begin{array}{c}-0.022 \\
(0.041)\end{array}$ & $\begin{array}{c}-0.008 \\
(0.040)\end{array}$ & $\begin{array}{c}0.115 \\
(0.046)\end{array}$ & $\begin{array}{c}0.115 \\
(0.044)\end{array}$ & $\begin{array}{c}0.052 \\
(0.028)\end{array}$ \\
\hline $\begin{array}{l}\text { Labor Market Outcomes (age } \geq 22 \text { ) } \\
\text { Worked during the year }\end{array}$ & 0.827 & $\begin{array}{l}-0.025 \\
(0.001)\end{array}$ & $\begin{array}{l}-0.024 \\
(0.001)\end{array}$ & $\begin{array}{l}-0.011 \\
(0.036)\end{array}$ & $\begin{array}{c}0.000 \\
(0.032)\end{array}$ & $\begin{array}{c}0.063 \\
(0.044)\end{array}$ & $\begin{array}{c}0.072 \\
(0.043)\end{array}$ & $\begin{array}{c}0.032 \\
(0.025)\end{array}$ \\
\hline Weekly labor force participation & 0.817 & $\begin{array}{l}-0.020 \\
(0.001)\end{array}$ & $\begin{array}{l}-0.020 \\
(0.001)\end{array}$ & $\begin{array}{c}0.006 \\
(0.038)\end{array}$ & $\begin{array}{c}0.003 \\
(0.034)\end{array}$ & $\begin{array}{c}0.018 \\
(0.043)\end{array}$ & $\begin{array}{c}0.033 \\
(0.043)\end{array}$ & $\begin{array}{c}0.015 \\
(0.026)\end{array}$ \\
\hline Hours worked last week & 32.6 & $\begin{array}{l}-1.06 \\
(0.05)\end{array}$ & $\begin{array}{l}-1.20 \\
(0.06)\end{array}$ & $\begin{array}{l}-0.76 \\
(2.41)\end{array}$ & $\begin{array}{l}-0.04 \\
(2.14)\end{array}$ & $\begin{array}{l}1.46 \\
(2.06)\end{array}$ & $\begin{array}{c}1.06 \\
(1.98)\end{array}$ & $\begin{array}{c}0.65 \\
(1.42)\end{array}$ \\
\hline Monthly earnings (in 1995 Shekels) & 2,997 & $\begin{array}{l}-217 \\
(7.4)\end{array}$ & $\begin{array}{l}-179 \\
(8.0)\end{array}$ & $\begin{array}{l}-6.76 \\
(362)\end{array}$ & $\begin{array}{l}55.5 \\
(319)\end{array}$ & $\begin{array}{c}266 \\
(283.8)\end{array}$ & $\begin{array}{c}430 \\
(292)\end{array}$ & $\begin{array}{c}261 \\
(209)\end{array}$ \\
\hline Ln(monthly earnings) & 8.08 & $\begin{array}{l}-0.034 \\
(0.002)\end{array}$ & $\begin{array}{l}-0.025 \\
(0.002)\end{array}$ & $\begin{array}{c}-0.032 \\
(0.095)\end{array}$ & $\begin{array}{c}0.007 \\
(0.085)\end{array}$ & $\begin{array}{c}-0.053 \\
(0.092)\end{array}$ & $\begin{array}{c}-0.067 \\
(0.083)\end{array}$ & $\begin{array}{l}-0.026 \\
(0.057)\end{array}$ \\
\hline \multicolumn{9}{|l|}{ Marriage } \\
\hline Married on census day & 0.446 & $\begin{array}{c}0.023 \\
(0.001)\end{array}$ & $\begin{array}{c}0.020 \\
(0.001)\end{array}$ & $\begin{array}{c}0.039 \\
(0.028)\end{array}$ & $\begin{array}{c}0.056 \\
(0.025)\end{array}$ & $\begin{array}{c}0.118 \\
(0.034)\end{array}$ & $\begin{array}{c}0.101 \\
(0.032)\end{array}$ & $\begin{array}{c}0.074 \\
(0.019)\end{array}$ \\
\hline Married by age 21 (age $\geq 21)$ & 0.172 & $\begin{array}{c}0.027 \\
(0.001)\end{array}$ & $\begin{array}{c}0.022 \\
(0.001)\end{array}$ & $\begin{array}{c}-0.003 \\
(0.035)\end{array}$ & $\begin{array}{c}0.021 \\
(0.031)\end{array}$ & $\begin{array}{c}0.198 \\
(0.047)\end{array}$ & $\begin{array}{c}0.192 \\
(0.046)\end{array}$ & $\begin{array}{c}0.107 \\
(0.025)\end{array}$ \\
\hline \multicolumn{9}{|l|}{ Fertility (women only) } \\
\hline Number of own children & 1.00 & $\begin{array}{c}0.123 \\
(0.004)\end{array}$ & $\begin{array}{c}0.110 \\
(0.004)\end{array}$ & $\begin{array}{c}0.182 \\
(0.133)\end{array}$ & $\begin{array}{c}0.037 \\
(0.086)\end{array}$ & $\begin{array}{c}0.191 \\
(0.096)\end{array}$ & $\begin{array}{c}0.178 \\
(0.097)\end{array}$ & $\begin{array}{c}0.115 \\
(0.064)\end{array}$ \\
\hline Any children & 0.448 & $\begin{array}{c}0.126 \\
(0.001)\end{array}$ & $\begin{array}{c}0.019 \\
(0.001)\end{array}$ & $\begin{array}{c}0.093 \\
(0.057)\end{array}$ & $\begin{array}{c}0.012 \\
(0.036)\end{array}$ & $\begin{array}{c}0.136 \\
(0.041)\end{array}$ & $\begin{array}{c}0.134 \\
(0.041)\end{array}$ & $\begin{array}{c}0.078 \\
(0.026)\end{array}$ \\
\hline 2 or more children & 0.320 & $\begin{array}{c}0.030 \\
(0.001)\end{array}$ & $\begin{array}{c}0.023 \\
(0.001)\end{array}$ & $\begin{array}{c}0.084 \\
(0.050)\end{array}$ & $\begin{array}{c}0.042 \\
(0.032)\end{array}$ & $\begin{array}{c}0.080 \\
(0.035)\end{array}$ & $\begin{array}{c}0.076 \\
(0.036)\end{array}$ & $\begin{array}{c}0.061 \\
(0.024)\end{array}$ \\
\hline $\begin{array}{l}\text { Spouse's Outcomes (for married) } \\
\text { Years of schooling }\end{array}$ & 12.8 & $\begin{array}{l}-0.325 \\
(0.008)\end{array}$ & $\begin{array}{l}-0.173 \\
(0.009)\end{array}$ & $\begin{array}{l}-0.274 \\
(0.417)\end{array}$ & $\begin{array}{l}-0.155 \\
(0.324)\end{array}$ & $\begin{array}{c}0.333 \\
(0.438)\end{array}$ & $\begin{array}{c}0.263 \\
(0.421)\end{array}$ & $\begin{array}{l}-0.002 \\
(0.252)\end{array}$ \\
\hline Weekly labor force participation & 0.848 & $\begin{array}{l}-0.023 \\
(0.001)\end{array}$ & $\begin{array}{l}-0.023 \\
(0.001)\end{array}$ & $\begin{array}{l}-0.008 \\
(0.052)\end{array}$ & $\begin{array}{l}-0.012 \\
(0.039)\end{array}$ & $\begin{array}{c}0.033 \\
(0.040)\end{array}$ & $\begin{array}{c}0.035 \\
(0.039)\end{array}$ & $\begin{array}{c}0.011 \\
(0.028)\end{array}$ \\
\hline Monthly earnings (in 1995 Shekels) & 3,241 & $\begin{array}{l}-281 \\
(09)\end{array}$ & $\begin{array}{l}-223 \\
(10)\end{array}$ & $\begin{array}{c}112 \\
(582)\end{array}$ & $\begin{array}{l}-241 \\
(437)\end{array}$ & $\begin{array}{c}518 \\
(720)\end{array}$ & $\begin{array}{c}425 \\
(658)\end{array}$ & $\begin{array}{l}92.9 \\
(356)\end{array}$ \\
\hline
\end{tabular}

Notes: The table reports means of the dependent variables (column 1) and coefficients on number of children for OLS models (columns 2-3) and 2SLS models using different sets of instruments (columns 4-8). Instruments with an 'aa' suffix are interaction terms with an AA dummy. The sample includes first borns from families with 2 or more births as decribed in Table 1. OLS estimates for column 2 include indicators for age and sex. Estimates for columns 3-8 are from models that include the control variables specified in Table3. Robust standard errors are reported in parenthesis. 


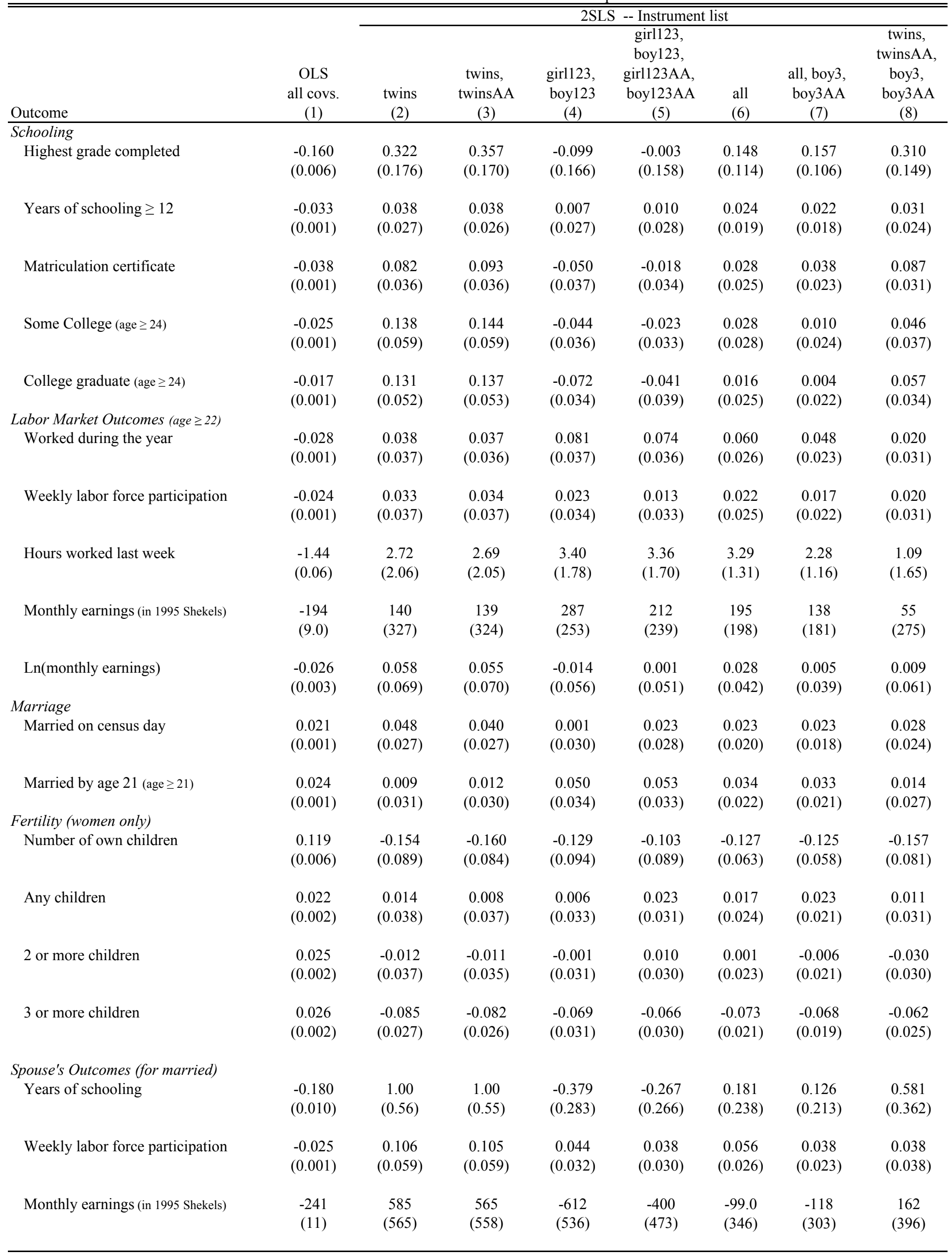

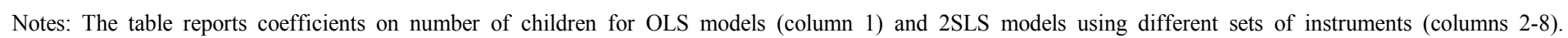

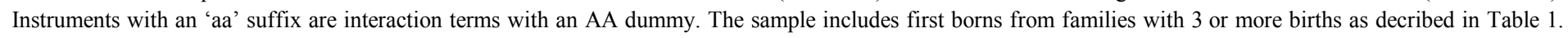
Regression estimates are from models that include the control variables specified in Table 3 . Robust standard errors are reported in parenthesis 


\begin{tabular}{|c|c|c|c|c|c|c|c|c|}
\hline \multirow[b]{2}{*}{ Outcome } & \multirow[b]{2}{*}{$\begin{array}{c}\text { OLS } \\
\text { all covs. } \\
(1)\end{array}$} & \multicolumn{7}{|c|}{ 2SLS -- Instrument list } \\
\hline & & $\begin{array}{l}\text { twins } \\
(2)\end{array}$ & $\begin{array}{c}\text { twins, } \\
\text { twinsAA } \\
(3)\end{array}$ & $\begin{array}{c}\text { girl123, } \\
\text { boy123 } \\
(4)\end{array}$ & $\begin{array}{c}\text { girl123, } \\
\text { boy123, } \\
\text { girl123AA, } \\
\text { boy123AA } \\
(5)\end{array}$ & $\begin{array}{l}\text { all } \\
(6)\end{array}$ & $\begin{array}{c}\text { all, boy3, } \\
\text { boy3AA } \\
(7)\end{array}$ & $\begin{array}{c}\text { twins, } \\
\text { twinsAA, } \\
\text { boy3, } \\
\text { boy3AA } \\
(8)\end{array}$ \\
\hline \multicolumn{9}{|l|}{ Schooling } \\
\hline Highest grade completed & $\begin{array}{c}-0.143 \\
(0.005)\end{array}$ & $\begin{array}{c}0.167 \\
(0.119)\end{array}$ & $\begin{array}{c}0.187 \\
(0.111)\end{array}$ & $\begin{array}{l}-0.108 \\
(0.134)\end{array}$ & $\begin{array}{l}-0.054 \\
(0.120)\end{array}$ & $\begin{array}{c}0.076 \\
(0.081)\end{array}$ & $\begin{array}{c}0.080 \\
(0.077)\end{array}$ & $\begin{array}{c}0.175 \\
(0.101)\end{array}$ \\
\hline Years of schooling $\geq 12$ & $\begin{array}{l}-0.031 \\
(0.001)\end{array}$ & $\begin{array}{c}0.025 \\
(0.019)\end{array}$ & $\begin{array}{c}0.025 \\
(0.018)\end{array}$ & $\begin{array}{c}0.001 \\
(0.023)\end{array}$ & $\begin{array}{l}-0.007 \\
(0.022)\end{array}$ & $\begin{array}{c}0.016 \\
(0.014)\end{array}$ & $\begin{array}{c}0.012 \\
(0.013)\end{array}$ & $\begin{array}{c}0.017 \\
(0.017)\end{array}$ \\
\hline Matriculation certificate & $\begin{array}{l}-0.033 \\
(0.001)\end{array}$ & $\begin{array}{c}0.057 \\
(0.026)\end{array}$ & $\begin{array}{c}0.065 \\
(0.026)\end{array}$ & $\begin{array}{l}-0.019 \\
(0.030)\end{array}$ & $\begin{array}{c}0.008 \\
(0.027)\end{array}$ & $\begin{array}{c}0.036 \\
(0.019)\end{array}$ & $\begin{array}{c}0.042 \\
(0.018)\end{array}$ & $\begin{array}{c}0.069 \\
(0.023)\end{array}$ \\
\hline Some College (age $\geq 24$ ) & $\begin{array}{l}-0.021 \\
(0.001)\end{array}$ & $\begin{array}{c}0.061 \\
(0.037)\end{array}$ & $\begin{array}{c}0.062 \\
(0.036)\end{array}$ & $\begin{array}{l}-0.047 \\
(0.030)\end{array}$ & $\begin{array}{l}-0.022 \\
(0.025)\end{array}$ & $\begin{array}{c}0.010 \\
(0.021)\end{array}$ & $\begin{array}{c}0.002 \\
(0.018)\end{array}$ & $\begin{array}{c}0.024 \\
(0.027)\end{array}$ \\
\hline College graduate (age $\geq 24$ ) & $\begin{array}{c}-0.015 \\
(0.001)\end{array}$ & $\begin{array}{c}0.065 \\
(0.036)\end{array}$ & $\begin{array}{c}0.068 \\
(0.037)\end{array}$ & $\begin{array}{l}-0.056 \\
(0.026)\end{array}$ & $\begin{array}{c}-0.031 \\
(0.022)\end{array}$ & $\begin{array}{c}0.003 \\
(0.019)\end{array}$ & $\begin{array}{c}-0.001 \\
(0.016)\end{array}$ & $\begin{array}{c}0.037 \\
(0.024)\end{array}$ \\
\hline \multicolumn{9}{|l|}{ Labor Market Outcomes (age $\geq 22$ ) } \\
\hline Worked during the year & $\begin{array}{l}-0.027 \\
(0.001)\end{array}$ & $\begin{array}{c}0.029 \\
(0.025)\end{array}$ & $\begin{array}{c}0.034 \\
(0.024)\end{array}$ & $\begin{array}{c}0.038 \\
(0.029)\end{array}$ & $\begin{array}{c}0.035 \\
(0.027)\end{array}$ & $\begin{array}{c}0.037 \\
(0.018)\end{array}$ & $\begin{array}{c}0.039 \\
(0.017)\end{array}$ & $\begin{array}{c}0.043 \\
(0.021)\end{array}$ \\
\hline Weekly labor force participation & $\begin{array}{l}-0.023 \\
(0.001)\end{array}$ & $\begin{array}{c}0.028 \\
(0.025)\end{array}$ & $\begin{array}{c}0.035 \\
(0.024)\end{array}$ & $\begin{array}{l}-0.001 \\
(0.028)\end{array}$ & $\begin{array}{l}-0.006 \\
(0.026)\end{array}$ & $\begin{array}{c}0.011 \\
(0.018)\end{array}$ & $\begin{array}{c}0.018 \\
(0.016)\end{array}$ & $\begin{array}{c}0.040 \\
(0.021)\end{array}$ \\
\hline Hours worked last week & $\begin{array}{l}-1.41 \\
(0.05)\end{array}$ & $\begin{array}{c}2.38 \\
(1.48)\end{array}$ & $\begin{array}{c}2.53 \\
(1.45)\end{array}$ & $\begin{array}{c}1.44 \\
(1.36)\end{array}$ & $\begin{array}{c}1.56 \\
(1.28)\end{array}$ & $\begin{array}{c}2.29 \\
(0.97)\end{array}$ & $\begin{array}{c}2.11 \\
(0.89)\end{array}$ & $\begin{array}{c}2.59 \\
(1.26)\end{array}$ \\
\hline Monthly earnings (in 1995 Shekels) & $\begin{array}{l}-185 \\
(6.77)\end{array}$ & $\begin{array}{l}46.6 \\
(207)\end{array}$ & $\begin{array}{l}63.4 \\
(206)\end{array}$ & $\begin{array}{c}127 \\
(176)\end{array}$ & $\begin{array}{c}115 \\
(162)\end{array}$ & $\begin{array}{c}103 \\
(131)\end{array}$ & $\begin{array}{c}107 \\
(122)\end{array}$ & $\begin{array}{c}96 \\
(180)\end{array}$ \\
\hline Ln(monthly earnings) & $\begin{array}{l}-0.027 \\
(0.002)\end{array}$ & $\begin{array}{c}0.017 \\
(0.048)\end{array}$ & $\begin{array}{c}0.011 \\
(0.049)\end{array}$ & $\begin{array}{c}0.013 \\
(0.050)\end{array}$ & $\begin{array}{c}0.031 \\
(0.046)\end{array}$ & $\begin{array}{c}0.038 \\
(0.033)\end{array}$ & $\begin{array}{c}0.019 \\
(0.031)\end{array}$ & $\begin{array}{c}0.005 \\
(0.042)\end{array}$ \\
\hline \multicolumn{9}{|l|}{ Marriage } \\
\hline Married on census day & $\begin{array}{c}0.020 \\
(0.001)\end{array}$ & $\begin{array}{c}0.022 \\
(0.018)\end{array}$ & $\begin{array}{c}0.016 \\
(0.018)\end{array}$ & $\begin{array}{c}0.019 \\
(0.024)\end{array}$ & $\begin{array}{c}0.041 \\
(0.022)\end{array}$ & $\begin{array}{c}0.022 \\
(0.014)\end{array}$ & $\begin{array}{c}0.015 \\
(0.013)\end{array}$ & $\begin{array}{c}0.006 \\
(0.016)\end{array}$ \\
\hline Married by age 21 (age $\geq 21$ ) & $\begin{array}{c}0.024 \\
(0.001)\end{array}$ & $\begin{array}{c}0.029 \\
(0.021)\end{array}$ & $\begin{array}{c}0.027 \\
(0.023)\end{array}$ & $\begin{array}{c}0.044 \\
(0.031)\end{array}$ & $\begin{array}{c}0.050 \\
(0.030)\end{array}$ & $\begin{array}{c}0.039 \\
(0.019)\end{array}$ & $\begin{array}{c}0.035 \\
(0.017)\end{array}$ & $\begin{array}{c}0.018 \\
(0.019)\end{array}$ \\
\hline \multicolumn{9}{|l|}{ Fertility (women only) } \\
\hline Number of own children & $\begin{array}{c}0.118 \\
(0.004)\end{array}$ & $\begin{array}{l}-0.069 \\
(0.066)\end{array}$ & $\begin{array}{c}-0.077 \\
(0.061)\end{array}$ & $\begin{array}{l}-0.079 \\
(0.069)\end{array}$ & $\begin{array}{c}-0.043 \\
(0.064)\end{array}$ & $\begin{array}{l}-0.058 \\
(0.045)\end{array}$ & $\begin{array}{l}-0.076 \\
(0.043)\end{array}$ & $\begin{array}{l}-0.097 \\
(0.059)\end{array}$ \\
\hline Any children & $\begin{array}{c}0.023 \\
(0.001)\end{array}$ & $\begin{array}{c}0.020 \\
(0.029)\end{array}$ & $\begin{array}{c}0.014 \\
(0.028)\end{array}$ & $\begin{array}{l}-0.003 \\
(0.025)\end{array}$ & $\begin{array}{c}0.012 \\
(0.022)\end{array}$ & $\begin{array}{c}0.013 \\
(0.017)\end{array}$ & $\begin{array}{c}0.010 \\
(0.016)\end{array}$ & $\begin{array}{c}0.006 \\
(0.025)\end{array}$ \\
\hline 2 or more children & $\begin{array}{c}0.025 \\
(0.001)\end{array}$ & $\begin{array}{l}-0.002 \\
(0.026)\end{array}$ & $\begin{array}{l}-0.005 \\
(0.024)\end{array}$ & $\begin{array}{l}-0.007 \\
(0.023)\end{array}$ & $\begin{array}{c}0.007 \\
(0.021)\end{array}$ & $\begin{array}{c}0.002 \\
(0.016)\end{array}$ & $\begin{array}{l}-0.005 \\
(0.015)\end{array}$ & $\begin{array}{l}-0.016 \\
(0.022)\end{array}$ \\
\hline 3 or more children & $\begin{array}{c}0.026 \\
(0.001)\end{array}$ & $\begin{array}{l}-0.050 \\
(0.020)\end{array}$ & $\begin{array}{c}-0.047 \\
(0.019)\end{array}$ & $\begin{array}{c}-0.042 \\
(0.021)\end{array}$ & $\begin{array}{l}-0.037 \\
(0.020)\end{array}$ & $\begin{array}{c}-0.041 \\
(0.014)\end{array}$ & $\begin{array}{c}-0.041 \\
(0.013)\end{array}$ & $\begin{array}{l}-0.037 \\
(0.018)\end{array}$ \\
\hline \multicolumn{9}{|l|}{ Spouse's Outcomes (for married) } \\
\hline Years of schooling & $\begin{array}{l}-0.166 \\
(0.008)\end{array}$ & $\begin{array}{c}0.539 \\
(0.308)\end{array}$ & $\begin{array}{c}0.552 \\
(0.294)\end{array}$ & $\begin{array}{l}-0.325 \\
(0.225)\end{array}$ & $\begin{array}{l}-0.233 \\
(0.201)\end{array}$ & $\begin{array}{c}0.106 \\
(0.162)\end{array}$ & $\begin{array}{c}0.095 \\
(0.145)\end{array}$ & $\begin{array}{c}0.389 \\
(0.218)\end{array}$ \\
\hline Weekly labor force participation & $\begin{array}{c}-0.023 \\
(0.001)\end{array}$ & $\begin{array}{c}0.043 \\
(0.034)\end{array}$ & $\begin{array}{c}0.037 \\
(0.033)\end{array}$ & $\begin{array}{c}0.026 \\
(0.024)\end{array}$ & $\begin{array}{c}0.010 \\
(0.020)\end{array}$ & $\begin{array}{c}0.020 \\
(0.017)\end{array}$ & $\begin{array}{c}0.012 \\
(0.016)\end{array}$ & $\begin{array}{c}0.014 \\
(0.024)\end{array}$ \\
\hline Monthly earnings (in 1995 Shekels) & $\begin{array}{l}-217 \\
(9.0)\end{array}$ & $\begin{array}{c}429 \\
(350)\end{array}$ & $\begin{array}{c}426 \\
(345)\end{array}$ & $\begin{array}{l}-889 \\
(414)\end{array}$ & $\begin{array}{l}-442 \\
(322)\end{array}$ & $\begin{array}{l}-151 \\
(230)\end{array}$ & $\begin{array}{l}-250 \\
(202)\end{array}$ & $\begin{array}{c}-77 \\
(253)\end{array}$ \\
\hline
\end{tabular}




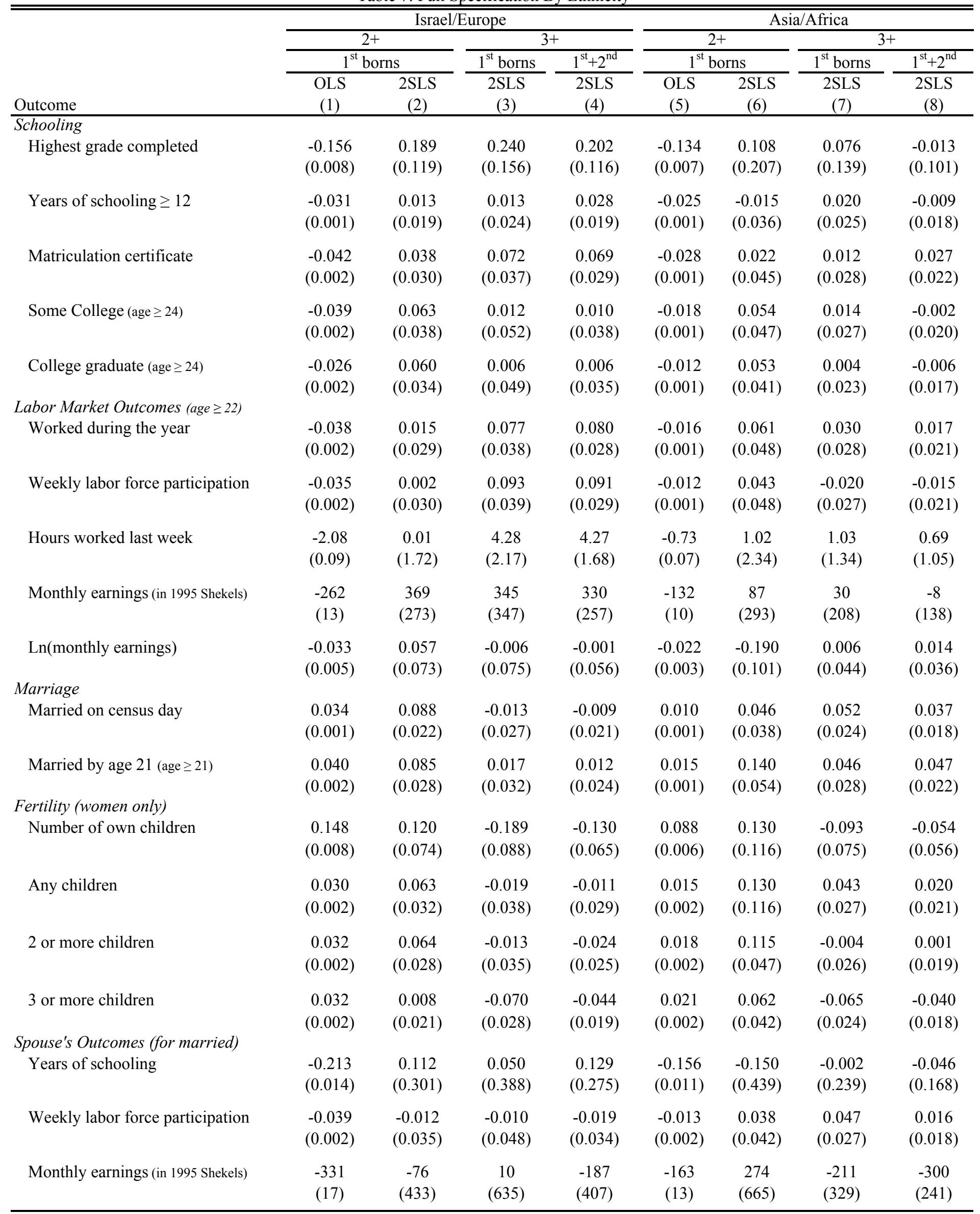

Notes: The table reports OLS and 2SLS results estimated separately by ethnicity.The 2SLS estimates are from models that include the full set of instruments (i.e. corresponding to column 8 in table 5 and column 7 in tables $6 \mathrm{a}$ and $6 \mathrm{~b}$ ). Regression estimates are from models that include the control variables specified in Table 3. Robust standard errors are reported in parenthesis. Standard errors for columns 4 and 8 are clustered by mother's ID. 


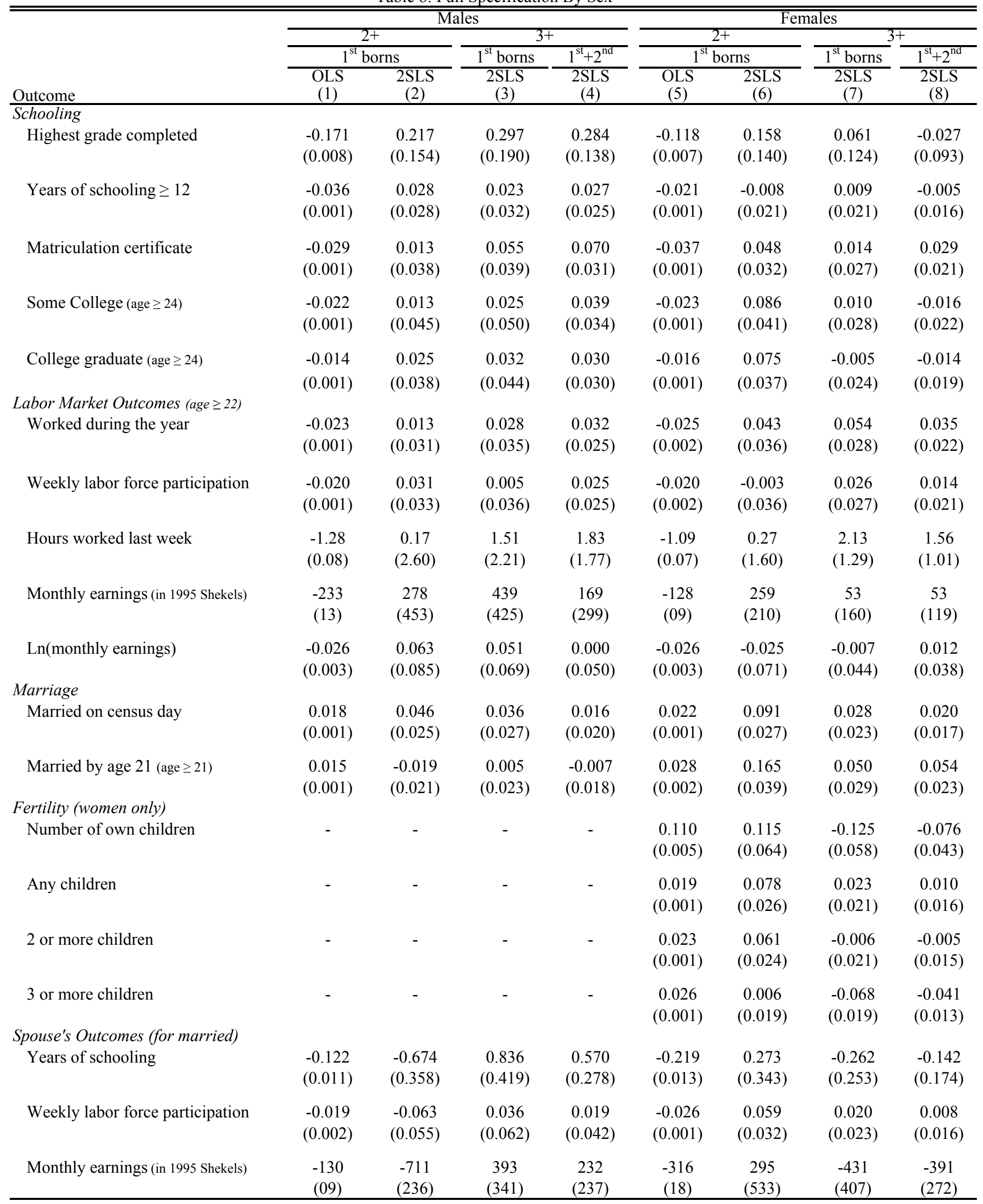

Notes: The table reports OLS and 2SLS results estimated separately for men and women.The 2SLS estimates are from models that include the full set of instruments (i.e. corresponding to column 8 in table 5 and column 7 in tables $6 \mathrm{a}$ and $6 \mathrm{~b}$ ). Regression estimates are from models that include the control variables specified in Table 3. Robust standard errors are reported in parenthesis. Standard errors for columns 4 and 8 are clustered by mother's ID. 

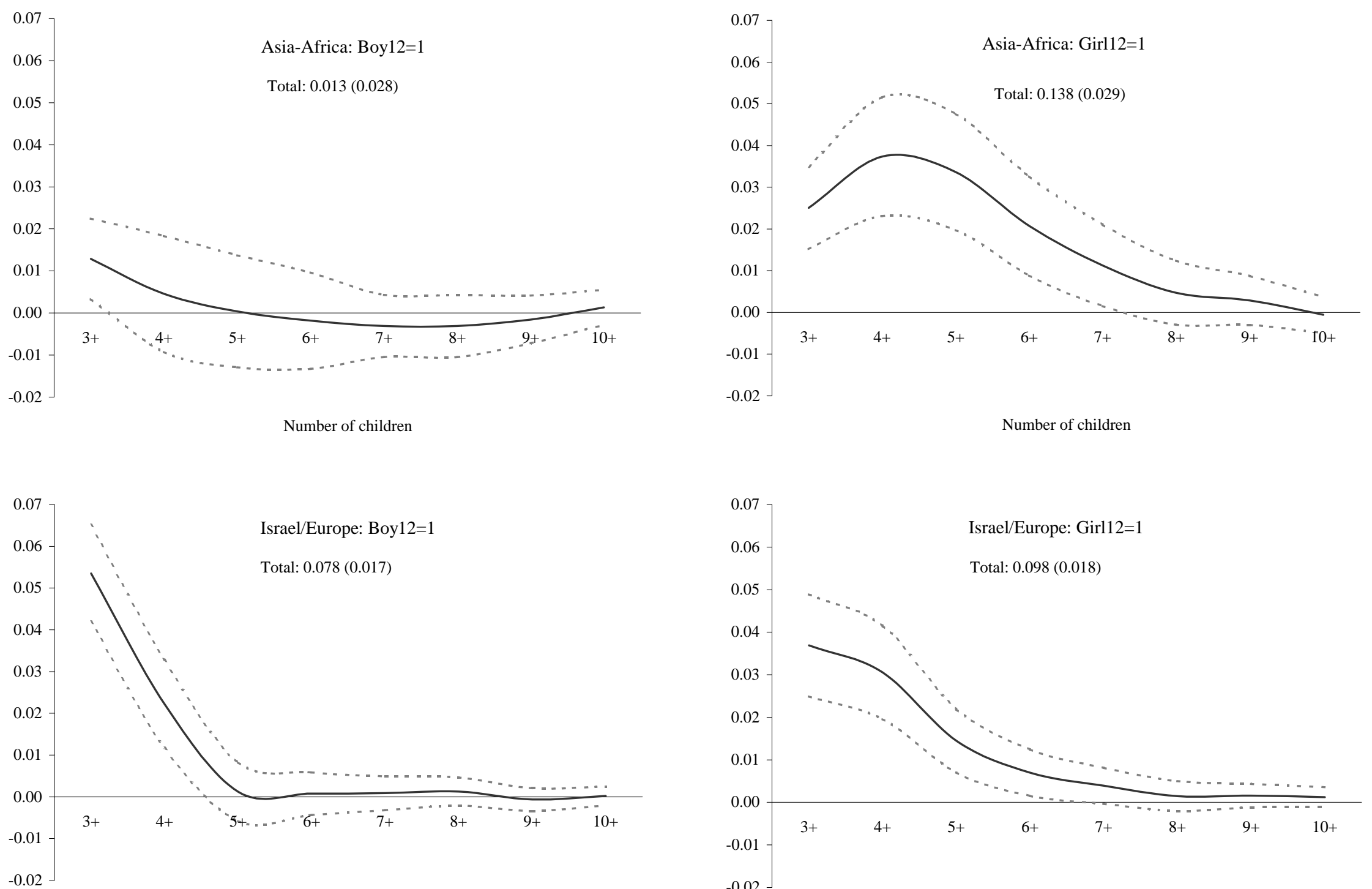

Number of children

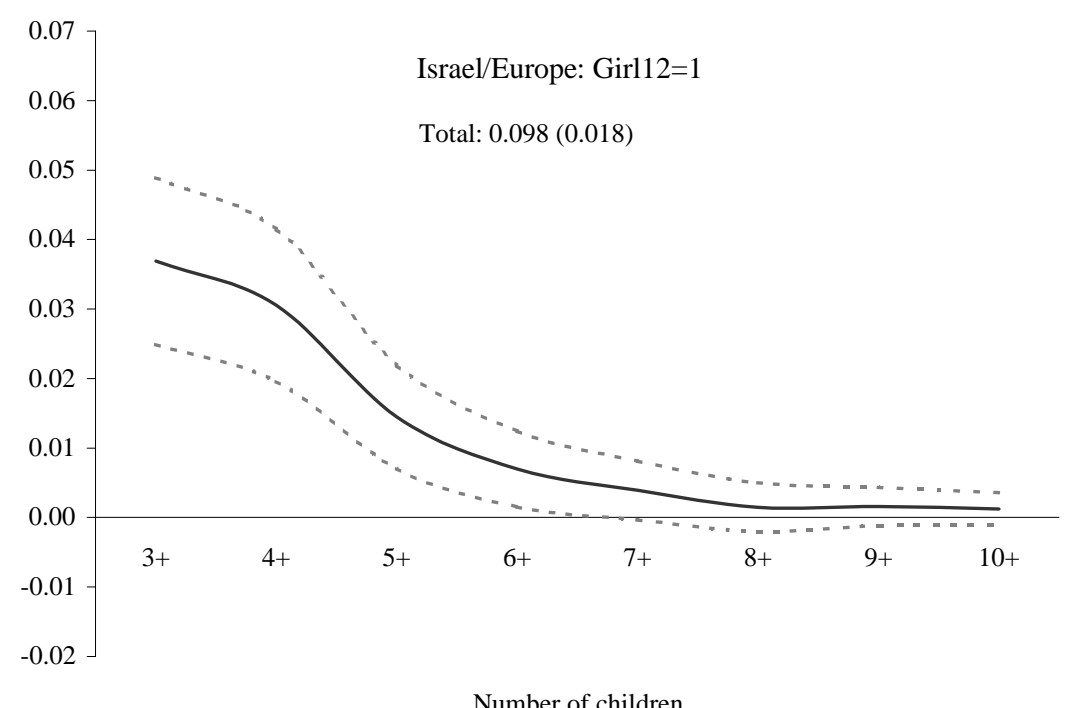

Figure 1: First-borns 2+ sample. First stage effects by ethnicity and type of sex-mix. 


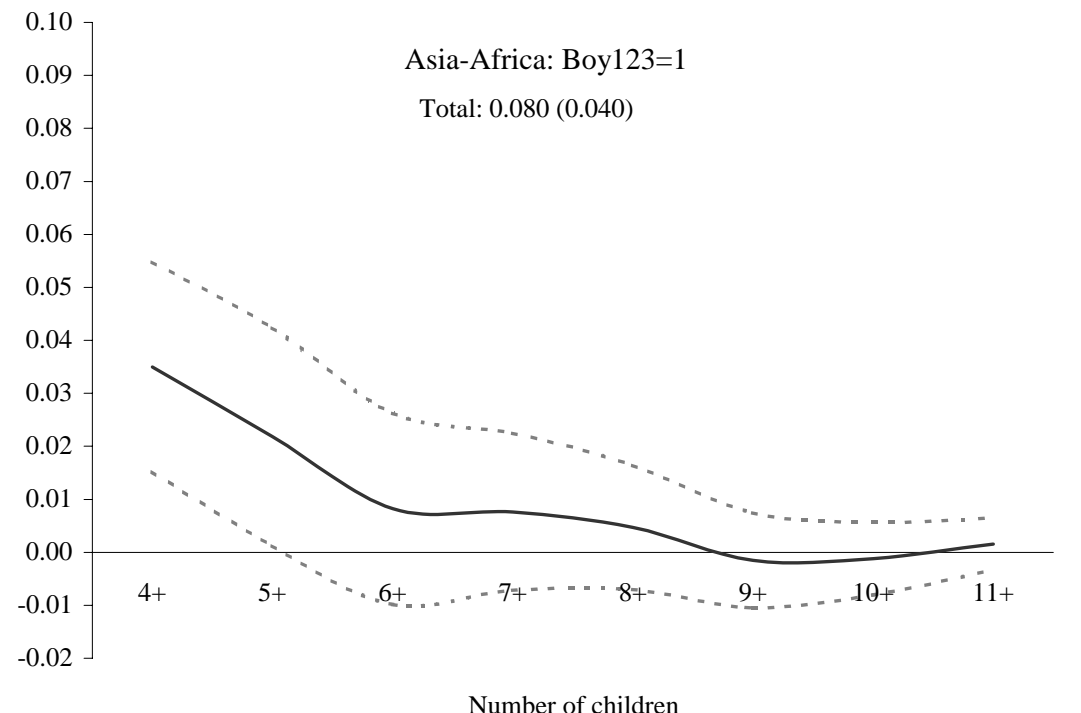

Number of children

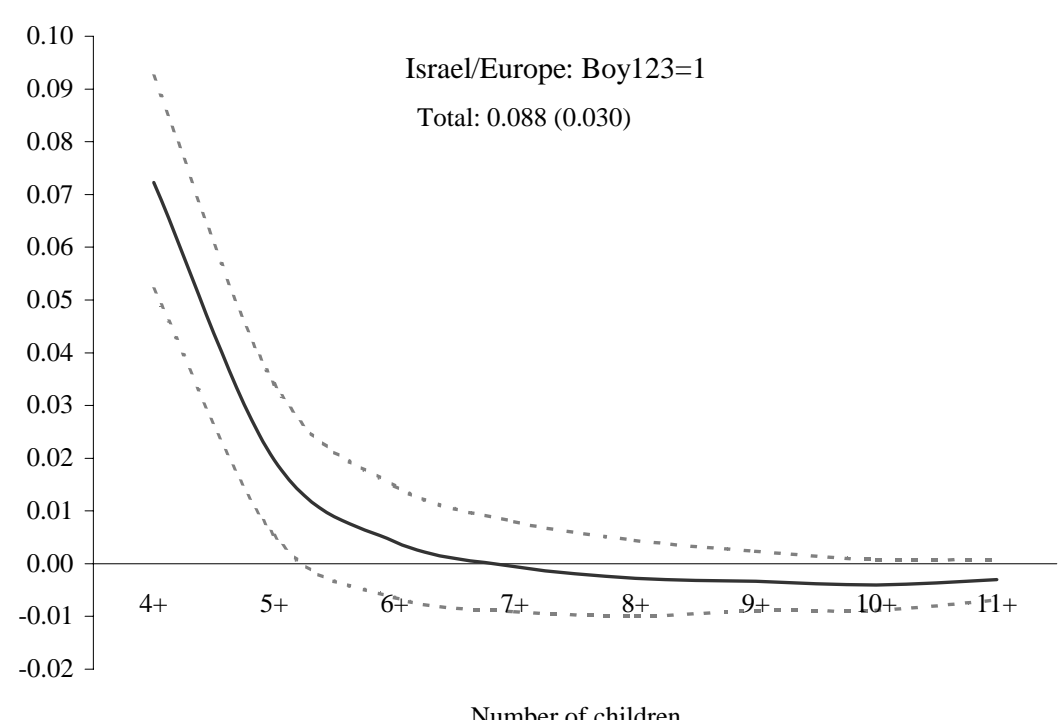

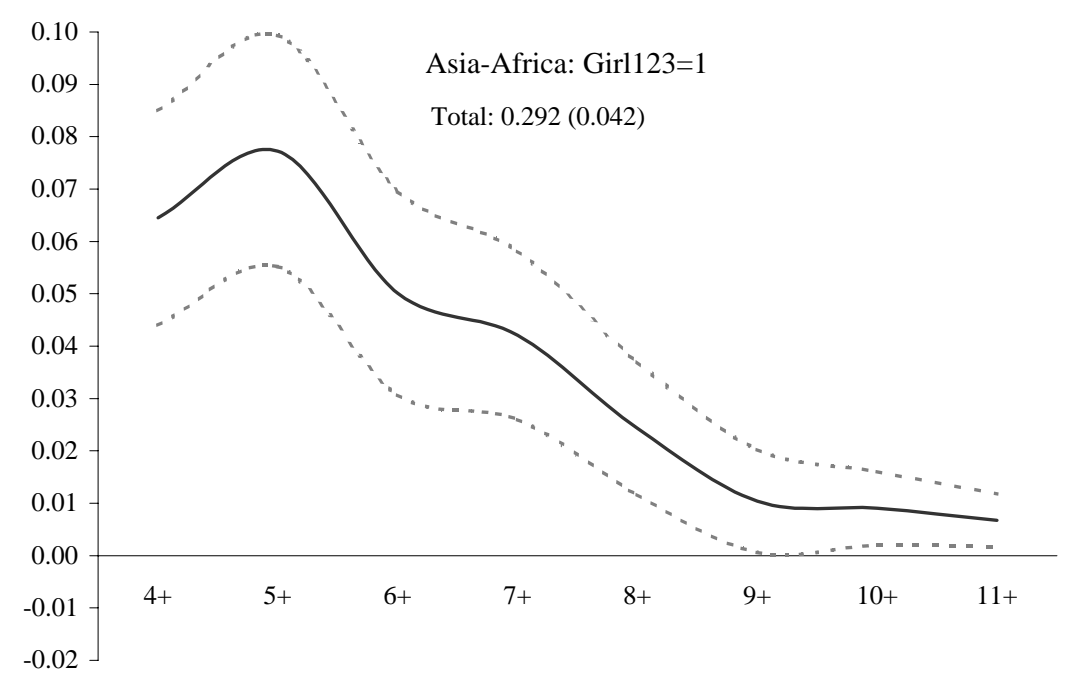

Number of children

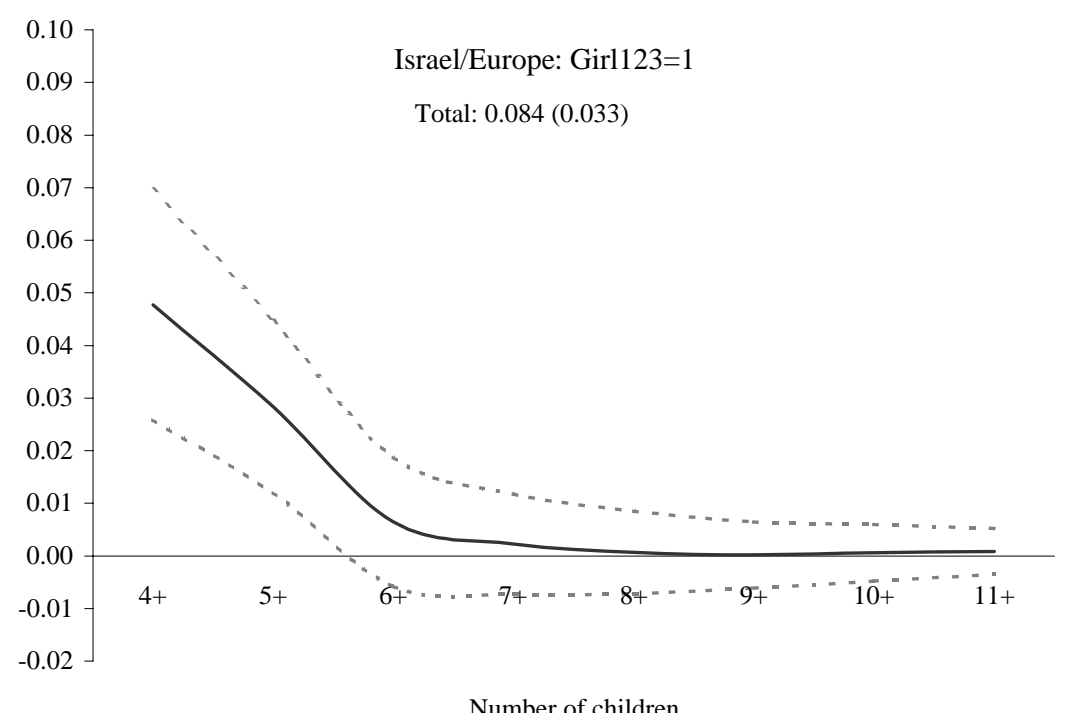

Figure 2: First borns 3+ sample. First stage effects by ethnicity and type of sex-mix (conditional on samesex12=1). 

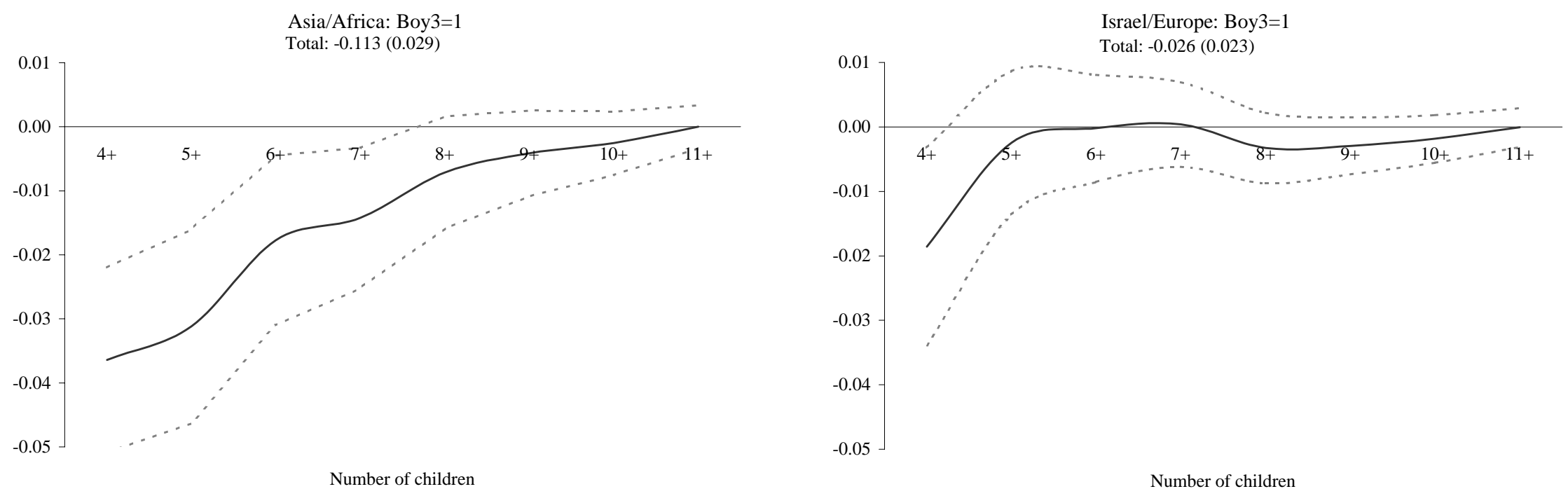

Figure 3: First borns 3+ sample. First stage effects of Boy3 (conditional on samesex12=0) 


\begin{tabular}{|c|c|c|c|}
\hline & $2+$ & & $3+$ \\
\hline & $\begin{array}{c}1^{\text {st }} \text { borns } \\
(1)\end{array}$ & $\begin{array}{c}1^{\text {st }} \text { borns } \\
(2)\end{array}$ & $\begin{array}{c}1^{\text {st }} \text { and } 2^{\text {nd }} \text { borns } \\
\text { (3) }\end{array}$ \\
\hline Twins & $\begin{array}{c}0.640 \\
(0.057)\end{array}$ & $\begin{array}{c}0.602 \\
(0.048)\end{array}$ & $\begin{array}{c}0.711 \\
(0.054)\end{array}$ \\
\hline Twins x Asia-Africa & $\begin{array}{l}-0.443 \\
(0.106)\end{array}$ & $\begin{array}{l}-0.109 \\
(0.100)\end{array}$ & $\begin{array}{l}-0.199 \\
(0.094)\end{array}$ \\
\hline Girls & $\begin{array}{c}0.090 \\
(0.017)\end{array}$ & $\begin{array}{c}0.102 \\
(0.032)\end{array}$ & $\begin{array}{c}0.082 \\
(0.027)\end{array}$ \\
\hline Girls x Asia-Africa & $\begin{array}{c}0.053 \\
(0.032)\end{array}$ & $\begin{array}{c}0.166 \\
(0.051)\end{array}$ & $\begin{array}{c}0.210 \\
(0.043)\end{array}$ \\
\hline Boys & $\begin{array}{c}0.061 \\
(0.017)\end{array}$ & $\begin{array}{c}0.103 \\
(0.029)\end{array}$ & $\begin{array}{c}0.075 \\
(0.025)\end{array}$ \\
\hline Boys x Asia-Africa & $\begin{array}{l}-0.045 \\
(0.030)\end{array}$ & $\begin{array}{l}-0.014 \\
(0.047)\end{array}$ & $\begin{array}{l}-0.146 \\
(0.040)\end{array}$ \\
\hline Boy3 x (1-samesex12) & - & $\begin{array}{l}-0.049 \\
(0.023)\end{array}$ & $\begin{array}{l}-0.041 \\
(0.019)\end{array}$ \\
\hline Boy3 x (1-samesex12) x Asia-Africa & - & $\begin{array}{l}-0.057 \\
(0.035)\end{array}$ & $\begin{array}{l}-0.065 \\
(0.030)\end{array}$ \\
\hline Subect $=$ boy & $\begin{array}{c}0.012 \\
(0.017)\end{array}$ & $\begin{array}{c}0.018 \\
(0.023)\end{array}$ & $\begin{array}{c}0.005 \\
(0.149)\end{array}$ \\
\hline$($ Subject $=$ boy $) \times$ Asia-Africa & $\begin{array}{c}0.007 \\
(0.031)\end{array}$ & $\begin{array}{l}-0.005 \\
(0.035)\end{array}$ & $\begin{array}{c}0.016 \\
(0.223)\end{array}$ \\
\hline Asia-Africa & $\begin{array}{c}0.242 \\
(0.024)\end{array}$ & $\begin{array}{c}0.190 \\
(0.032)\end{array}$ & $\begin{array}{c}0.103 \\
(0.025)\end{array}$ \\
\hline
\end{tabular}

Notes: The table reports first-stage effects on number of children using the full set of instruments. The regression estimates are from models that include the control variables specified in Table 3. Robust standard errors are reported in parenthesis. Standard errors in column 3 are clustered by mother's ID. 